\title{
Equity Market Globalization and Portfolio Rebalancing
}

\author{
Kyungkeun Kim*, Dongwon Lee**
}

The views expressed herein are those of the authors and do not necessarily reflect the official views of the Bank of Korea. When reporting or citing this paper, the authors' names should always be explicitly stated.

* Economist, Economic Research Institute, The Bank of Korea, Tel: +82-2-759-5396, E-mail:kkkim@bok.or.kr. ** Assistant Professor of Economics, University of California, Riverside, E-mail: dongwon.lee@ucr.edu.

The authors are grateful for comments received on the earlier versions of this article from Yu-chin Chen, Stephan Siegel, Fabio Ghironi, Philip Brock, Dae Hwan Kim, Taek Ho Kwon, and Vincent Dropsy. The authors would also like to thank Jieun Lee, Young Ju Kim and other anonymous referees for their valuable comments. 


\section{Contents}

I . Introduction ………………………………………………… 1

II. Theoretical Background and Identification Strategy $\cdots \cdots . .7$

III. Empirical Methodology ………………………………..... 16

IV. Estimation Results ………………………………......... 20

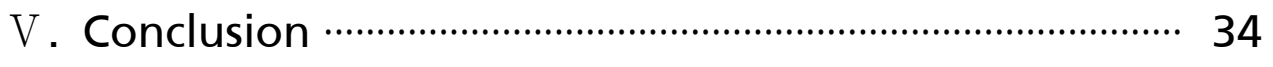

References …………………………………………………… 36

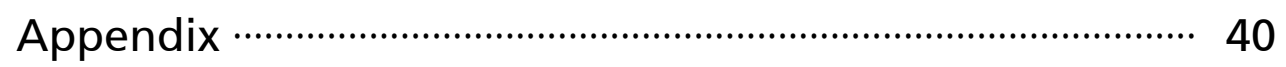




\section{Equity Market Globalization and Portfolio Rebalancing}

This paper examines how the financial globalization affects international equity mutual funds' portfolio choices in emerging markets. By examining the monthly holdings of 155 international funds, we first show that these funds actively engage in a rebalancing strategy to maintain their risk preferences upon realization of excess return changes. We also document robust evidence that these funds' propensity of rebalancing is larger in a country whose equity market is more strongly correlated with the global market. The results help understand how the financial globalization may raise the portfolio risk of the international funds' equity holdings in emerging economies.

Keywords: Equity market globalization, Portfolio allocation, Portfolio rebalancing, Return correlation

JEL Classification: F3, G11, G15 


\section{Introduction}

Foreign equity investment has accounted for a growing proportion of cross-border capital flows for emerging market economies in the last couple of decades. Increasing access to foreign financial markets has allowed a large degree of risk sharing and diversification in both domestic and foreign individuals and institutions. However, it also brings about a more frequent occurrence of asset price bubbles, credit booms, and capital flow reversals that make local markets more vulnerable to external shocks and often precede costly currency crises. The recent surge in international financial integration also suggests that the importance of country factors has declined and that of global factors has begun to play a more crucial role in explaining international portfolio returns (Campa and Fernandes, 2006; Chan et al., 2005). With a greater degree of financial globalization and increasing volume of equity trading, stock returns exhibit a high degree of co-movement worldwide, implying that the risk of equity portfolio investment in a country may come not only from the local equity market but also from its link with the global market.

In the earlier literature, investors' portfolio allocation decisions are generally studied based on idiosyncratic determinants such as country- or industry-level factors (Thapa and Poshakwale, 2012). This paper departs from the literature's standard focus and underscores the importance of global common factor on the equity portfolio investments. In particular, using the information for international equity mutual funds' allocation across emerging market economies, we attempt to answer the following questions: i) how do international funds respond to the excess relative return changes in their equity portfolios?; and ii) how do their responses differ between countries that have a heterogeneous exposure to the global stock market movements?

While seeking answers to these questions, this paper contributes to the existing literature along two dimensions. First, based on the comprehensive micro-level data, the paper's aim is to generalize the trading patterns of mutual funds in allocating international equity portfolios. Although there is the vast literature on how the portfolio investors react to return changes of host country 
assets for their international portfolios, empirical evidence regarding the allocation strategies is mixed: studies supporting the return chasing (or positive feedback trading) include Bohn and Tesar (1996), Brennan and Cao (1997), Froot et al. (2001), and Kaminsky et al. (2004), while other studies such as Calvet et al. (2009), Curcuru et al. (2011, 2014), and Hau and Rey (2004, 2006, 2008) find evidence consistent with portfolio rebalancing. A consensus is far from being reached and the reasons for this disagreement in previous empirical results are due in part to the data structure (bilateral flows vs. portfolio allocations), choice of sample countries and periods, and underlying assumptions of asset returns. Our approach throws some light on this controversy by investigating the rich portfolio allocation data of international mutual funds whose portfolios cover all major emerging markets rather than advanced markets that the most of the aforementioned literature focuses on.

Second, our novel approach explores the impact of the global factor on international portfolio allocations in emerging market economies. Some of the earlier studies have looked at the link between the global common factors and 'aggregate' capital flows in recipient countries. For example, Calvo et al. (1996), Cerutti et al., (2014), Chuhan et al. (1998), Fernandez-Arias (1996), Forbes and Warnock (2012), Fratzscher (2012) and Ghosh et al. (2014) emphasize global push factors such as US interest rate movements and their impact on aggregate capital flows. Unlike the earlier literature, the global factor this paper considers is the world equity return. In particular, the paper investigates the correlation between the global and local equity returns as a measure of financial globalization and its marginal effect on the fund managers' international portfolio allocation choices. The fund-level micro data and portfolio-based techniques enable us to explore this new channel.

Emerging market countries have a different extent of linkage with the global market. To see the cross-country differences in the local and global equity market synchronization, we present in Figure 1 the time-varying correlations between the local and global equity returns in six emerging economies selected from our sample.1) The correlations are calculated over a 24 month rolling window and their line plots are displayed during the sample period. At first 
Figure 1: Heterogeneous Equity Market Globalization Based on Return

\section{Comovements}
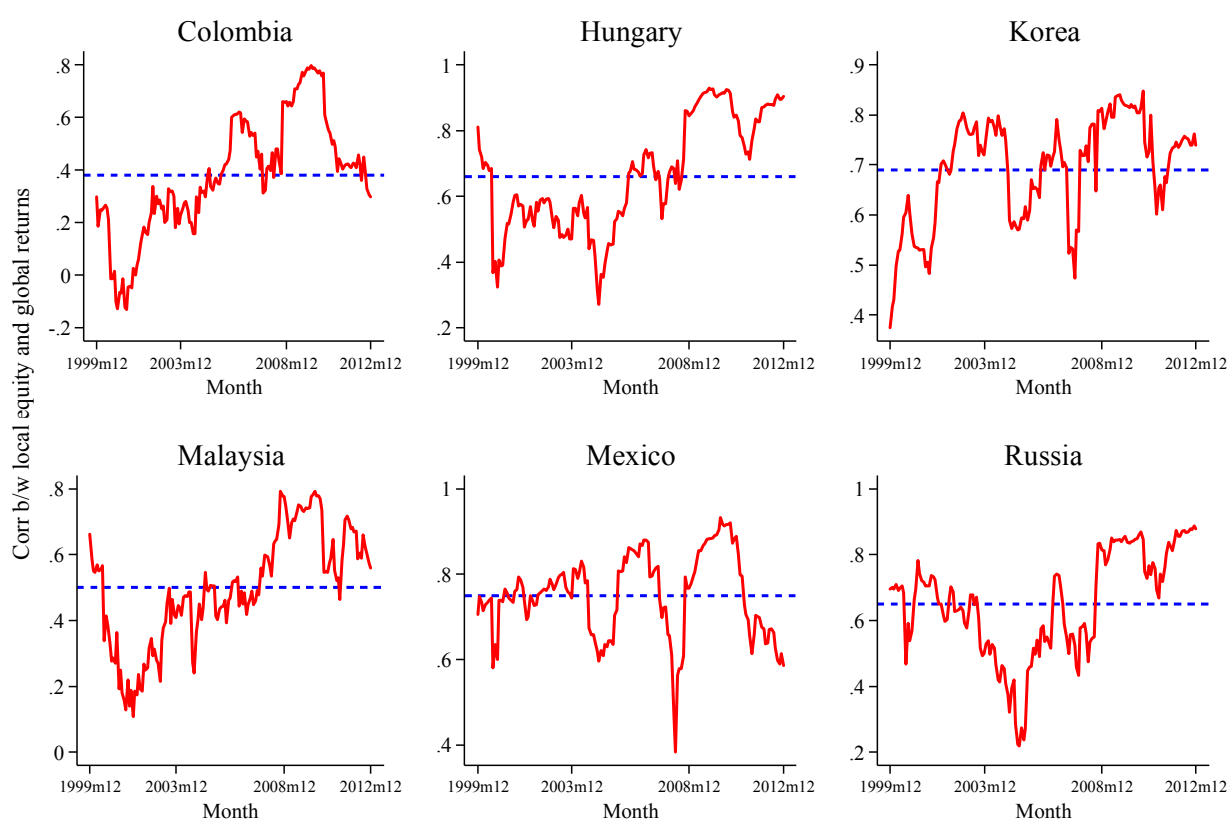

Return correlation between local and global equity markets

Note: The time-varying moving-window return correlations between the local (evaluated at the local currency) and global equity markets are calculated based on the monthly return data from January, 1998 to December, 2012 with a window size of 24 months and illustrated in a solid line. The dashed horizontal line indicates a period-average value of the rolling-window return correlation for each country: Colombia (0.38), Hungary (0.66), Korea (0.69), Malaysia (0.50), Mexico (0.75), Russia (0.65).

Source: Morgan Stanley Capital International (MSCl).

glance, we observe from Figure 1 that the connection between local and global equity markets has been quite strong with the period average return correlation of 0.61 from six selected countries, and has generally become stronger over

1) See column (1) of Table A1 in Appendix which summarizes the degree of the local equity market comovement with the global market for each of our sample countries. Note that the global return is measured by a change in the MSCI world index which is a country/sector weighted average of equity performance of 23 developed countries. The level of return comovement across countries is a standard measure of market integration often adopted in the literature (Longin and Solnik, 1995; Quinn and Voth, 2008). 
time. Moreover, there exists a large variation in the degree of local and global equity return comovements over time and across countries.2) This signals that countries have heterogeneous exposures to global equity market innovations. A stronger correlation means that a country's local financial market is more sensitive to the changes in external global factors, which can influence market participants' investment decisions.

In the next section, we first show our testable hypotheses based on a simple structural framework. A key assumption in our dynamic decision making process is that a risk-averse fund manager chooses her optimal diversification by maximizing risk-adjusted returns at the beginning of the first period. At the end of the first period, international portfolio returns are realized and they become a basis of the fund manager's reallocation decision at the beginning of the next period. Note that any drift from the initial optimal allocation means a higher portfolio risk as it deteriorates diversification gains. For example, a buy-and-hold (BH) strategy will have large county weights focused on appreciating countries' assets over time. This positive skew would be even more pronounced with a return chasing or positive feedback trading. As long as the host country's stock return follows a definite upward trend, the return chasing strategy can benefit the investor. On the other hand, active rebalancing mitigates the fluctuations in portfolio weights and maintains desired portfolio risk preferences over time.3)

By decomposing a country's total return into global and country-specific components, our framework also presents that the realized valuation changes can come from the domestic or global market fluctuations. Depending on the strength of local market co-movements with the global market, there may be a cross-country heterogeneity in the degree of portfolio rebalancing by

2) Evidence for time-varying world market integration in a number of emerging markets is also reported in Bekaert and Harvey (1995). They find that this time-varying nature of financial integration is attributable to the capital market reforms in emerging economies.

3) In practice, risk-averse investors who follow a rebalancing strategy reallocate away from a market whose relative weight in their portfolio deviates from a target allocation by a certain pre-specified threshold level, or on a regular basis, simply once every six or twelve months to maintain fixed bandwidths within which assets are allocated. 
international fund managers because of different world price of covariance risk.

We use micro-level panel data that come from the Emerging Portfolio Fund Research (EPFR) database to test our hypotheses. The international mutual funds in our sample hold only foreign assets in emerging economies with little to no home assets. The equity funds are considered only to focus on portfolio shifts across countries and exclude the possibility of shifts across asset classes. The selected database tracks allocation information of 155 equity mutual funds domiciled in 13 advanced countries such as euro zone, United Kingdom and United States for 26 destination countries during the period 1999m12-2012m12. The fund-level data set gives us the unique ability to relate a destination country's relative returns to each equity fund's country allocation weights.

Our empirical findings can be summarized as follows. We find evidence that there is a negative and statistically significant relationship between a country weight of the international portfolio and the country's relative equity return (to the portfolio average return), revealing the prevalence of portfolio rebalancing strategies in emerging market equity trading. This result, based on the allocation data of international funds whose portfolio includes only foreign country assets, complements the existing portfolio rebalancing literature that typically studies the reallocations of assets between home and foreign countries. Our result also demonstrates that a host country's higher equity return correlation with the global return leads to even stronger rebalancing actions of international mutual funds. According to our theoretical framework, this is because the emerging stock markets that are more sensitive to global return movements would be subject to stronger valuation effects. Actively rebalanced portfolio would mitigate the valuation effects of asset return changes and keep the fund managers' preferred risk exposure over time.

In order to test the robustness of our main results, we control for other relevant country specific conditions that might confound the impact of realized valuation changes on portfolio reallocation decisions. The host country's equity market risk measured by an equity return variance shock, choice of exchange rate regimes to account for the currency risk, and stock market size are added to our baseline regression model. We continue to find robust rebalancing 
behavior of emerging market funds and a consistently positive relation between the extent of equity market interdependence with the global market and the degree of rebalancing. Regarding the impact of those additional control variables on portfolio rebalancing, two findings are worth mentioning. When an emerging equity market with a currency peg uses the same currency as a fund domicile's, the fund manager finds no currency risk and reallocates her equity holdings from such a country less actively with a lower degree of rebalancing. This result corroborates the currency-risk driven rebalancing hypothesis of Hau and Rey (2006, 2008). On the other hand, the large market size appears to trigger a greater degree of rebalancing. This is because the development of the large market may be attributable to the low transaction costs and high transparency, which would make portfolio adjustments less costly.

We also test how portfolio reallocation strategies have changed during the 2008-09 global crisis by running rolling window regressions for the entire sample period. Evidence reveals that with a relatively higher risk aversion and return volatility, the fund managers respond more sensitively to realized return changes from emerging markets during the crisis compared to the tranquil periods. Additionally, the propensity of rebalancing appears remarkably higher from more globalized stock markets during the period of financial turmoil which originated in advanced economies.

In short, more integrated equity markets are more sensitive to the changes in global common factors, leading to a higher portfolio risk of the equity funds resulting from a greater valuation effect. Portfolio rebalancing is a strategic reaction of the fund managers to meet their diversification objectives by hedging overall portfolio risks. Since this rebalancing strategy requires sales of outperforming assets and purchases of underperforming assets, it may partly contribute to lessening the volatility of the host country's equity market as well as the volatility of the fund managers' portfolio. This inference arises due to its counter-cyclical nature of the portfolio reallocation strategy.

The rest of the paper proceeds as follows. Section 2 sketches theoretical background for international portfolio adjustments upon realization of relative returns and presents our regression model specifications. Section 3 describes 
the fund-level data on country allocation and their sources. The main empirical results and their robustness tests are reported in Section 4. Finally, Section 5 concludes.

\section{Theoretical Background and Identification Strategy}

In this section, we use a simple dynamic decision making environment to describe international mutual fund's portfolio managements for equity capital. Following a mean-variance approach to portfolio selection pioneered by Markowitz (1952) and recently adopted in Chan et al. (2005), Hau and Rey (2006, 2008), Fidora et al. (2007), Edison and Warnock (2008), Kim (2011), and Ding and Ma (2013), the optimal portfolio weights are determined with an objective of maximizing the risk-adjusted total return.4) We assume that this optimal diversification decision is made at the beginning of the first period; and at the beginning of the next period, portfolio reallocation takes place upon realization of the total return.5) Decomposing the total return into local and global components, our framework is able to show how a change in the global common factor brings a heterogeneous impact on a country's total return and asset valuation effect. This section is admittedly very simple, but it surely helps understand our hypotheses and regression model specifications.

\section{The Initial Optimal Portfolio Allocation}

Let's assume that a representative fund manager is risk-averse and holds equity mutual funds that are invested in multiple foreign countries with uncertain returns. Her expected utility takes the following mean-variance function:

4) Our approach is different from $\operatorname{Kim}$ (2011) in that nominal exchange rates are embedded in total returns and the decomposition between local-currency priced equity returns and exchange rate returns is not taken into account. This set-up may be less general than Kim (2011)'s but is consistent with our empirical specifications.

5) Note that the total return refers to a combination of the local-currency priced equity return and exchange rate return (change in the value of a local currency against the US dollar). 


$$
\begin{gathered}
\max U=\mathrm{w}^{\prime} E[r]-\frac{\lambda}{2} \mathrm{w}^{\prime} \Sigma \mathrm{w} \\
\text { s.t. } \mathrm{w}^{\prime} I=1
\end{gathered}
$$

where $\mathrm{w}$ is a $(J \times 1)$ vector of country weights where $\mathrm{w}_{j}$ is the $j^{\text {th }}$ element, $E[\cdot]$ is the standard expectation operator, $r$ is a $(J \times 1)$ vector of total returns from each country $j$ equity holdings, $\lambda$ is the coefficient of absolute risk aversion, $\Sigma$ is the covariance matrix of expected asset returns, and $I$ is a unity column vector.6) The constraint means all wealth is allocated in risky securities of $J$ countries. Let's simplify the constraint and assume that a portfolio includes equity securities in countries $j$ and $j$. To facilitate interpretations, let's assume that $j$ refers to a group of countries in the fund's portfolio other than country $j$ such that

$$
\mathrm{w}_{j}+\mathrm{w}_{j^{*}}=1
$$

Solving the constrained maximization problem (1) with the simplifying assumption (2), the optimal portfolio weight for country $j$, which represents the fund manager's optimal allocation of her wealth to each of $J$ risky assets at the beginning of the first period, is as follows:

$$
\mathrm{w}_{j}=\frac{E\left[r_{j}-r_{j^{*}}\right]+\lambda\left\{\operatorname{var}\left(r_{j^{*}}\right)-\operatorname{cov}\left(r_{j}, r_{j^{*}}\right)\right\}}{\lambda\left\{\operatorname{var}\left(r_{j}\right)-\operatorname{var}\left(r_{j^{*}}\right)-2 \operatorname{cov}\left(r_{j}, r_{j^{*}}\right)\right\}}
$$

where we denote by $r_{j}$ and $r_{j^{*}}$ the total return from country $j$ and $j^{*}$. For expositional simplicity, Equation (3) omits time subscripts. Note that the optimal diversification given in Equation (3) reflects the fund's optimal trade-off between the expected relative return and risk for assets allocated in different countries. A simple interpretation is that, given other things constant,

6) The coefficient of absolute risk aversion $\lambda$ is originally from a constant absolute risk aversion (CARA) utility function. 
the higher relative return or lower relative risk in country $j$ attracts greater volume of capital inflows and increases country $j$ share $\left(\mathrm{w}_{j}\right)$ in the fund's portfolio.

\section{Passive and Active Reallocation Strategies}

Once the total return changes are observed at the end of the first period, there are two actions from which a fund manager chooses: passive holding or active reallocation strategy. Certainly, this choice may also depend on the fund manager's risk preferences, liquidity needs, required transaction costs and the underlying asset's expected return behavior. We abstract away from all these considerations and pay our attention on the valuation channel to account for the portfolio risk and its impact on the reallocation strategies.

Following Curcuru et al. (2011, 2014), we define a BH or passive weight as Equation (4) below, which is the next period's conditional country $j$ share if fund manager $i$ does not trade assets after observing returns at the end of period 1:

$$
\left(\mathrm{w}_{i j, t+1}^{B H} \mid r_{j, t+1}, r_{i, t+1}\right)=\mathrm{w}_{i j, t}\left(\frac{1+r_{j, t+1}}{1+r_{i, t+1}}\right)
$$

where $\mathrm{w}_{i j, t}$ is an initial optimal weight given by Equation (3); $r_{j, t+1}$ is the total return from country $j$ at the end of period 1 ; and $r_{i, t+1}$ is fund $i$ s weighted average portfolio return at the end of period 1 defined as

$$
r_{i, t+1}=\sum_{j=1}^{J} \mathrm{w}_{i j, t} r_{j, t+1}
$$

Equation (4) shows that a BH weight will move in the same direction as country $j$ s realized relative return (over the portfolio average return).

On the other hand, if the fund manager actively reallocates her portfolio given the return changes, country $j$ share at the beginning of the next period will deviate from the passive $\mathrm{BH}$ weight. In order to measure this active 
reallocation strategy, we decompose the change of country $j$ s asset share into active and passive components as follows:

$$
\Delta \mathrm{w}_{i j, t+1}=\mathrm{w}_{i j, t+1}-\mathrm{w}_{i j, t} \underbrace{\left(\frac{1+r_{j, t+1}}{1+r_{i, t+1}}\right)}_{\text {valuation effect }}
$$

Notice that the second term on the right-hand-side of Equation (6) is the $\mathrm{BH}$ weight shown in Equation (4). Therefore, under the passive holding, $\Delta \mathrm{w}_{i j, t+1}=0$ from Equation (6) at time $t+1$. When country $j$ s equity market outperforms fund $i$ s average portfolio at the end of period 1 , country $j$ weight in fund is portfolio at time $t+1$ automatically rises due to the valuation effect. By eliminating the valuation effect from country $j$ weight at time $t+1$, Equation (6) allows us to track the fund manager's active portfolio management behavior and identify actual (relative) demand for country $j$ assets that is independent of the wealth effect. For example, $\Delta \mathrm{w}_{i j, t+1}>0$ from Equation (6) given the relative country $j$ return over the portfolio average return reflects a fund manager's return chasing or positive feedback trading (i.e. buy assets when prices rise and sell when prices fall). Conversely, $\Delta \mathrm{w}_{i j, t+1}<0$ given the relative country $j$ return captures the fund manager's rebalancing behavior (i.e. realign portfolio weights back to the initial optimal allocation by selling winners and by buying losers). The return chasing strategy will benefit the investor only if country $j$ s total return exhibits an upward trend with little volatility and its success largely depends on the return predictability. Rebalanced portfolios will neutralize compounding effect resulting from the total return and valuation changes and maintain fund managers' original risk preferences.

\section{Two Sources for Excess Relative Returns: Local and Global Components}

We now consider a simple decomposition of the total return into local and global components to illustrate how a change in the global common factor brings a heterogeneous impact to a country's total return and asset valuation effect at time $t+1$. The motivation of the total return decomposition into the 
global and country-specific factors comes from the implications of Figure 1; the global return accounts for a substantial extent of the emerging market economies' equity returns, indicating the presence of the global common factor between the market movements. Miranda-Agrippino and Rey (2015) also adopt a similar return decomposition.

First of all, let's assume that country $j$ s total return is driven by the global common factor $(G)$, country-specific factor $\left(C_{j}\right)$ and an error term $\left(\varepsilon_{j}\right)$ that is not explained by $G$ and $C_{j}$ as follows:

$$
r_{j, t+1}=a_{j}+b_{j}^{g} G_{t+1}+b_{j}^{c} C_{j, t+1}+\varepsilon_{j, t+1}
$$

where $a_{j}$ is a constant representing the intercept; factor loadings $b_{j}^{g}$ and $b_{j}^{c}$ are assumed to be constant over time but can vary across countries; and $\varepsilon_{j, t+1}$ is an idiosyncratic disturbance term that is not cross-sectionally correlated.7) The factor loadings $b_{j}^{g}$ and $b_{j}^{c}$ reflect the degree to which variation in $r_{j, t+1}$ can be explained by each factor. In order for $G_{t+1}$ to fully capture the common factor across countries, $C_{j, t+1}$ is assumed to be uncorrelated across countries. Note that the global common factor $G_{t+1}$ has a heterogeneous effect on country $j \mathrm{~s}$ total return depending on the size of factor loading $b_{j}^{g}$. Our analysis takes a global return in the equity market as a global common factor. Then, the coefficient $b_{j}^{g}$ measures country $j$ s degree of return synchronization with the global market.

Finally, substituting Equation (7) into (4) yields

$$
\left(\mathrm{w}_{i j, t+1}^{B H} \mid r_{j, t+1}, r_{i, t+1}\right)=\mathrm{w}_{i j, t}\left(\frac{1+a_{j}+b_{j}^{g} G_{t+1}+b_{j}^{c} C_{j, t+1}+\varepsilon_{j, t+1}}{1+r_{i, t+1}}\right)
$$

Given all other things constant, when country $j$ s total return becomes higher

7) We could have assumed time-varying factor loadings in Equation (7). This would not change the main implication of our structural model. 
than fund $i$ s average portfolio return at time $t+1$ due to an increase in $C_{j, t+1}$, Equation (8) implies that a $\mathrm{BH}$ country $j$ share will have an upward drift from the initial optimal diversification. In contrast, the relatively poorer local market condition with lower $C_{j, t+1}$ will automatically reduce the passive country $j$ weight at time $t+1$.

As financial market integration progresses, the relative importance of country factors has declined while global factors have begun to explain significant portion of international equity portfolio returns (Campa and Fernandes, 2006). So, let's now consider the global bull market that has a world-wide impact through higher $G_{t+1}$ at the end of period 1. Holding all other things being constant but $b_{j}^{g}>b_{j^{*}}^{g}>0$, Equation (8) indicates that a rise in $G_{t+1}$ has a larger positive impact on country $j$ return than country $j$ return, generating a more pronounced valuation effect for country $j$ weight. That is, the financial market integration makes a country's total return sensitive to not only internal but also external market condition changes, and the effect of the latter is bigger for the equity market that is more strongly linked to the global factor.

One may ask what is a dominating channel, either the local-currency priced equity return or exchange rate return, through which the global factor $(G)$ influences country $j$ s total return. We conjecture that the transmission comes mainly through the local equity return rather than the currency return based on empirical evidence provided in Figure 2. By comparing two plots in Figure 2, we find that the local-currency priced equity return is the one that accounts for a significant portion of the correlation between the total and global returns instead of the currency return. On average, about 92 percent of the correlation between a country's total return and global return is explained by the correlation between the underlying equity market return (in a local currency) and global return. See Table Al in Appendix for relevant statistics.

As summarized in Equation (8), both local and global equity market booms tend to raise country $j$ s total return and the size of valuation, causing the country's passive weight to be inconsistent with the original diversification objective. How international equity fund managers react to the changes in realized relative total return will be determined by the prevailing tendency among the fund managers in the sample. In the next subsection, we present the regression model specifications and testable hypotheses. 
Figure 2: Evidence of Equity Market Globalization through Local Equity

Return

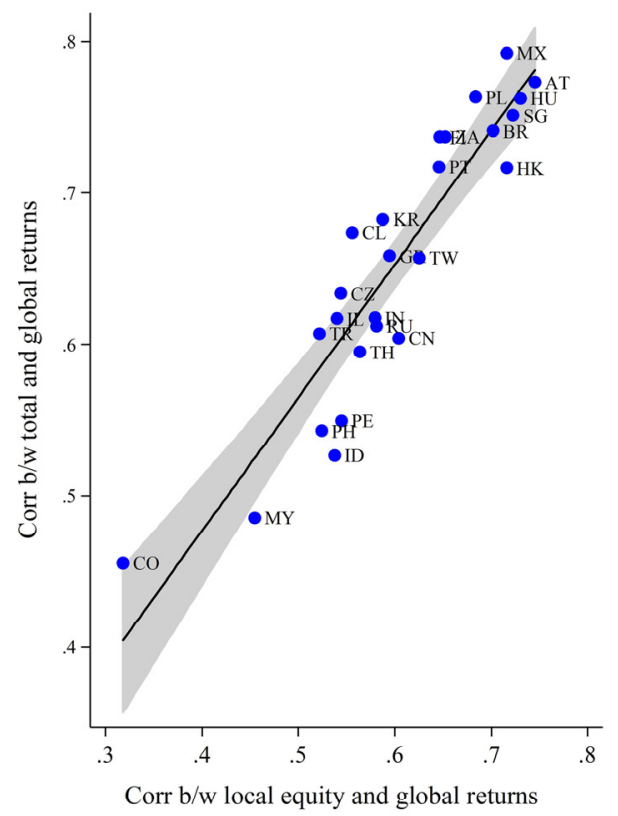

$95 \%$ confidence interval

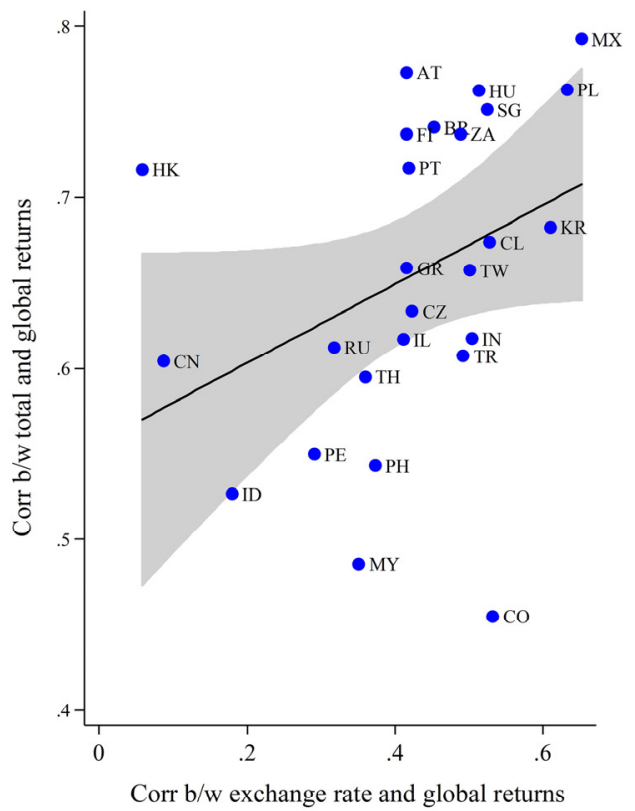

Fitted line

Note: The local equity returns are evaluated at the local currency. The sample period runs from $1998 \mathrm{~m} 1$ to 2012m12. Country abbreviations: Austria (AT), Brazil (BR), Chile (CL), China (CN), Colombia (CO), Czech Republic (CZ), Finland (FI), Greece (GR), Hong Kong (HK), Hungary (HU), India (IN), Indonesia (ID), Israel (IL), Korea (KR), Malaysia (MY), Mexico (MX), Peru (PE), Philippines (PH), Poland (PL), Portugal (PT), Russia (RU), Singapore (SG), South Africa (ZA), Taiwan (TW), Thailand (TH), and Turkey (TR). Source: Bloomberg and MSCl.

\section{Regression Model Specification and Testable Hypotheses}

Fund managers are heterogeneous: They trade assets at different times; moreover, they have different minimum thresholds for changes in return and risk characteristics, inducing some funds to adjust their portfolios while keeping others inactive even when exposed to the return shocks of similar size. For this reason, our empirical procedure based on a panel dataset tries to discover the average tendency of international equity mutual funds' reaction to relative return changes. 
In order to test the relationship between the relative total returns and the corresponding country weight changes, we use the following panel fixed-effect regression model: for fund $i$, country $j$ and time $t$,

$$
\Delta \mathrm{w}_{i j, t}=\alpha_{i j}+\beta\left(r_{j, t}-r_{i, t}\right)+u_{i j, t}
$$

where $\Delta \mathrm{w}_{i j, t}$ is a change in fund is country $j$ share at time $t$ as defined in Equation (6), $\alpha_{i j}$ controls for a time-invariant fund-host country fixed effect; $\left(r_{j, t}-r_{i, t}\right)$ is country $j$ s relative total return over the fund $i$ s average portfolio return; and $u_{i j, t}$ is a disturbance term. ${ }^{8)}$ Testing mutual funds' portfolio choices using realized relative returns as a main explanatory variable such as Equation (9) is a standard approach in the literature.9) One important identification advantage of specification (9) with the fund-level portfolio allocation data is to worry less about endogeneity resulting from reverse causality than the empirical models that involve aggregate capital flows. This is because the direction of causality is clear from a country's total return changes to the fund's country weight changes and not vice versa. Another identification advantage of our portfolio-based approach is the absence of an inference problem associated with the wealth effect as pointed out by Curcuru et al. (2011). For example, a US investor who recently experiences an increase in her wealth may distribute the excess wealth to all assets in her international portfolio, but at the same time

8) In theory, we could have added underlying equity returns and currency returns as separate regressors instead of the total return alone. However, in practice, doing so raises a multicollinearity concern due to the correlation between local equity and currency returns as the uncovered equity parity (UEP) literature (Cappiello and De Santis, 2005; Hau and Rey, 2006; Kim, 2011; and Curcuru et al., 2014) suggests. According to UEP, when the foreign equity market outperforms the domestic market, the domestic currency is expected to appreciate due to portfolio rebalancing; facing a relatively higher foreign exchange risk arising from the increased foreign share in her portfolio, the investor repatriates some of her foreign equity holdings and uses the proceeds to buy domestic equity assets. On the technical front, extracting the common component between local equity and currency returns requires one to make ad hoc assumptions about the return processes. These are the main reasons that we keep a total return as a regressor in our empirical model.

9) The baseline regression model in Hau and Rey (2008) uses the same specification as in Equation (9). An augmented model of Equation (9) is adopted in Raddatz and Schmukler (2012) by adding a crisis dummy variable. 
lower a particular country's portfolio share as the size of its return improvement is not as large as other countries' in her portfolio. By observing the larger aggregate capital inflows to the host country and the higher underlying equity market return, bilateral flows-based research may draw a misleading conclusion that the US investor chases returns, while a portfolio-based approach precisely points to portfolio rebalancing.

The first objective in the empirical analysis is to estimate and interpret the coefficient $\beta$ from Equation (9) in order to see the marginal effect of realized relative (total) returns on portfolio adjustments:

$$
\frac{\partial\left(\Delta \mathrm{w}_{i j, t} \mid r_{j, t}, r_{i, t}\right)}{\partial\left(r_{j, t}-r_{i, t}\right)}=\beta
$$

Note that a significant and negative (positive) coefficient $\beta$ from Equation (10) would suggest the international funds' rebalancing (return chasing or positive feedback trading) behavior. For a BH strategy, $\beta$ should be equal to zero.

The second step of our analysis studies the degree of correlation between country $j$ s local equity market return and global return and its impact on the propensity of rebalancing (or return chasing). To do so, we extend Equation (9) to come up with the following interaction variable model in a panel setting:

$$
\Delta \mathrm{w}_{i j, t}=\alpha_{i j}+\left(\beta+\sum_{k=1}^{3} \gamma_{k} g_{k, t}\right)\left(r_{j, t}-r_{i, t}\right)+\sum_{k=1}^{3} \delta_{k} g_{k, t}+e_{i j, t}
$$

where $g$ 's are local-global return correlation dummy variables that capture the relative strength of country $j$ s equity market globalization: $g_{1, t}$ takes a value of unity if a country's MSCI local return (evaluated at the local currency) correlation with the MSCI world return at time $t$ is greater than the upper quartile in the sample, $g_{2, t}$ if the correlation belongs to the interquartile range, and $g_{3, t}$ if it is smaller than the lower quartile.10) Because the local equity return

10) Forbes and Rigobon (2002) show that the simple cross-market correlation coefficients are biased measures of the market integration due to the heteroskedasticity in market returns. However, our measure of local and global market comovement is not fully subject to this critique because time-varying correlation 
correlation with the global return changes over time for each country as seen from Figure 1, the list of countries in each group varies over time and thus we keep time subscripts for binary variable $g$ 's. To interpret the parameter estimates, we take a partial derivative of Equation (11) with respect to the realized relative return $\left(r_{j, t}-r_{i, t}\right)$ to reach

$$
\frac{\partial\left(\Delta \mathrm{w}_{i j, t} \mid r_{j, t}, r_{i, t}, g_{k, t}\right)}{\partial\left(r_{j, t}-r_{i, t}\right)}=\beta+\gamma_{k} g_{k, t} \quad \text { for } k=1,2,3
$$

Equation (12) shows that the fund manager's propensity of rebalancing (or return chasing) depends on the conditional factor $g$ 's. By including different levels of country $j$ s equity market synchronization with the global market in Equation (11), the model allows us to test how the various levels of correlation affect fund manager's portfolio reallocation decisions differently. For instance, if equity fund managers' desire is to keep the original risk preferences by actively rebalancing their portfolios, we would expect a negative coefficient $\beta$ from Equation (10). Moreover, since the stronger comovement between the local and global equity returns tends to make the valuation effect larger given the other local and global market conditions, a buy-and-hold portfolio would be less diversified and riskier over time. As a result, we would expect to find the consistently higher degree of rebalancing in more integrated markets such that $\left(\beta+\gamma_{1}\right)<\left(\beta+\gamma_{2}\right)<\left(\beta+\gamma_{3}\right)<0$.

\section{Empirical Methodology}

\section{Data and Sources}

This paper employs a micro-level data set provided by the EPFR Global database that collects country allocation information directly from fund managers or administrators of international mutual funds. Our sample is in a

coefficients are ranked across sample countries in each period to form return correlation dummy variables. Indeed, we find that the country rank calculated from the heteroskedasticity-adjusted correlation coefficients is the same with the one from the simple correlation coefficients used in this paper. 
monthly frequency and includes 155 international equity mutual funds over the period 1999m12-2012m12. We focus on the international funds that target emerging markets for their equity investment destinations and hold little to no home assets.11) So, the analyses regarding the home bias and substitution between asset classes are not possible using our sample. It only allows portfolio shifts between countries for risky securities. In order for our empirical results to be immune to the outliers or inconsistency resulting from the emergence or disappearance of funds during the sample period, we drop funds whose total number of observations is less than 12 months. Moreover, small funds whose initial net asset value is less than 15 million US dollars are also excluded as they often report the data at less frequent intervals. Applying these data screening procedures leaves 26 host countries (20 emerging and 6 developed economies). A few developed countries remain in the sample because they still constitute a small fraction (less than 5\%) of portfolios for emerging market funds. All the major emerging equity markets around the globe are included in our sample and therefore our empirical results are unlikely to be sensitive to the data mining procedures. ${ }^{12)}$

The EPFR database reports fund name, investment recipient country and each fund's total net assets (TNA) denominated in US dollars, country allocation weights as a percentage share of the fund assets, and portfolio returns. The database also provides information about fund domiciles that are primarily located in advanced market jurisdictions including the euro zone, United Kingdom, and United States. Funds are different in investment scopes and are sorted by the fund domiciles and by the market segments. For example, Emerging Europe, Middle East, and Africa equity funds invest, on average, $41 \%$

11) Since this paper's main objective is to analyze the external factor in the form of correlation between the domestic equity return and global return and its effect on international funds' portfolio allocations, our sample includes emerging market funds only.

12) As for evidence of the representativeness of our data, Jotikasthira et al. (2012) find similar patterns for the EPFR portfolio flows data and the net foreign transactions of US investors reported in the Treasury International Capital System (TIC) by the U.S. Treasury department. There are a few more empirical studies that use the EPFR data including Broner et al. (2006), Forbes et al. (2016), Fratzscher (2012), Gelos and Wei (2005), Jotikasthira et al. (2012), Raddatz and Schmukler (2012), and Wei et al. (2010), all of which address different questions from ours. 
of their assets in Russia, $21 \%$ in South Africa, 14\% in Poland, and 9\% in Hungary. Table 1 displays detailed information about the EPFR data.

The other data come from various sources. The equity market returns in both daily and monthly time series for each country, target region and the world are from MSCI index, stock market capitalization (to measure the stock market size) from World Bank WDI, and exchange rate regime from Ilzetzki, Reinhart, and Rogoff (2010, IRR, hereafter). The daily spot exchange rates are from Bloomberg and these are recorded in the way that a higher value means a currency appreciation of the local market against the currency of the fund domicile. The total return from country $j$ equity holding is defined as a sum of the log difference of local MSCI indexes and the log difference of exchange rates between the host country and fund domicile over time. For example, the UK domiciled funds' total return from the equity investment in China is a combination of yuan-denominated local equity market return in China and a change in nominal exchange rates between the UK and China in a given time period. 


\section{BOK Working Paper No. 2017-17}

\section{Table 1: Snapshot of our Sample Data}

A. Fund domicile, target region and total net assets

\begin{tabular}{llll} 
Fund domicile & Fund target region & $\#$ of funds & TNA (\$US billions) \\
Euro zone & BRIC & 1 & 2.39 \\
& Emerging Europe, Middle East, and Africa & 22 & 95.21 \\
& Global Emerging & 16 & 173.05 \\
& Latin America & 6 & 21.90 \\
United Kingdom & BRIC & 0 & 0 \\
& Emerging Europe, Middle East, and Africa & 6 & 20.39 \\
& Global Emerging & 23 & 503.16 \\
United States & Latin America & 10 & 73.19 \\
& BRIC & 3 & 27.55 \\
& Emerging Europe, Middle East, and Africa & 7 & 10.97 \\
& Global Emerging & 54 & 1665.66 \\
& Latin America & 7 & 20.41 \\
$\quad$ Total & \multicolumn{1}{c}{155} & 2613.89 \\
\hline
\end{tabular}

B. Average country weights

\begin{tabular}{lllllllllll} 
Fund target region & \multicolumn{1}{l}{ Average weight } & & & & & & \\
BRIC & Brazil & China & India & Russia & & & & \\
& 0.34 & 0.36 & 0.13 & 0.15 & & & & \\
Emerging Europe, & Czech Rep. & Hungary & Poland & Russia & South Africa & Turkey \\
Middle East, and Africa & 0.06 & & 0.09 & & 0.14 & 0.41 & 0.21 & 0.07 \\
& Brazil & China & India & Korea & Mexico & Russia & South Africa & Taiwan \\
Global Emerging & 0.13 & 0.10 & 0.07 & 0.14 & 0.07 & 0.07 & 0.08 & 0.09 \\
Latin America & Brazil & Chile & Mexico & & & & & & \\
& 0.50 & 0.07 & 0.35 & & & & & & \\
\hline
\end{tabular}

C. Equity investment host countries in the sample

\begin{tabular}{|c|c|c|c|c|c|}
\hline \multirow{2}{*}{$\begin{array}{l}\text { Region } \\
\text { Class }\end{array}$} & \multirow{2}{*}{$\begin{array}{l}\text { Americas } \\
\text { Emerging }\end{array}$} & \multicolumn{2}{|c|}{ Asia \& Pacific } & \multicolumn{2}{|c|}{ Europe, Middle East \& Africa } \\
\hline & & Emerging & Developed & Emerging & Developed \\
\hline Countries & $\begin{array}{l}\text { Brazil } \\
\text { Chile } \\
\text { Colombia } \\
\text { Mexico } \\
\text { Peru }\end{array}$ & $\begin{array}{l}\text { China } \\
\text { India } \\
\text { Indonesia } \\
\text { Korea } \\
\text { Malaysia } \\
\text { Philippines } \\
\text { Taiwan } \\
\text { Thailand }\end{array}$ & $\begin{array}{l}\text { Hong Kong } \\
\text { Singapore }\end{array}$ & $\begin{array}{l}\text { Czech Rep. } \\
\text { Hungary } \\
\text { Israel } \\
\text { Poland } \\
\text { Russia } \\
\text { South Africa } \\
\text { Turkey }\end{array}$ & $\begin{array}{l}\text { Austria } \\
\text { Finland } \\
\text { Greece } \\
\text { Portugal }\end{array}$ \\
\hline
\end{tabular}

Note: This table presents detailed information about the EPFR data. In panel A, euro zone includes Austria, Belgium, Finland, France, Germany, Greece, Ireland, Italy, Netherlands, Portugal and Spain. Total net assets (TNA) are from the observations in December, 2012. In panel B, period-average country weights above $5 \%$ are included. In panel $\mathrm{C}$, countries are sorted based on the $\mathrm{MSCl}$ market classification in the middle of our sample period, 2005.

Source: Authors' calculations based on the data from EPFR, 1999m12-2012m12. 


\section{Estimation Results}

\section{Main Results}

This section presents our main empirical results. In the baseline results summarized in Table 2, we consider two estimation methods: pooled OLS and panel fixed-effect (FE) estimations based on two models specified in Equation (9) and Equation (11). While the pooled OLS specification addresses part of the between variation as well as within variation, the $\mathrm{FE}$ model focuses on the within variation and controls for time-invariant unobserved heterogeneity. For the pooled OLS, there is a high chance that the error term is correlated over time for each cross-sectional unit. When the serial correlation is present, the usual OLS standard errors are not appropriate as they are likely to be downward biased (Cameron and Trivedi, 2005). So, for a valid statistical inference, we cluster the standard errors around fund-country specific dimension for the pooled OLS model. On the other hand, the FE model employs heteroskedasticity- and autocorrelation-consistent Newey-West standard errors. In column (5) and column (6) of Table II, month-specific time effects are also controlled as well as fund-host country fixed effects in order to allow for any unobserved events and reforms with global impacts. ${ }^{13)}$

Column (1) and column (2) present pooled OLS results and column (3) through column (6) present FE estimation results. For all specifications, we find very robust and statistically significant evidence of portfolio rebalancing $(\beta<0$; we will call $\beta$ a rebalancing coefficient hereafter) by international fund managers for their holdings of foreign equities in emerging markets. Fund managers actively realign portfolio weights by selling relatively outperforming assets and by buying relatively underperforming assets to stabilize variation in country allocation weights over time. There is no difference in the coefficient estimates for realized relative returns across different panel estimation methods. Our findings corroborate the dominance of rebalancing strategy found in the

13) An unreported estimation also allows a domicile fixed effect and the main results remain robust. These results are available upon request. 


\section{Table 2. Portfolio Rebalancing and the Effect of Return Comovements}

\begin{tabular}{|c|c|c|c|c|c|c|}
\hline \multirow[b]{2}{*}{ Variable } & \multicolumn{2}{|c|}{ Pooled OLS } & \multicolumn{4}{|c|}{ Fixed-effect estimation } \\
\hline & (1) & (2) & (3) & (4) & (5) & (6) \\
\hline \multirow[t]{2}{*}{$r_{j, t}-r_{i, t}$} & $-0.62^{* * *}$ & $-0.18^{* * *}$ & $-0.62^{* * *}$ & $-0.18^{* * *}$ & $-0.55^{* * *}$ & $-0.11^{*}$ \\
\hline & $(0.06)$ & $(0.06)$ & $(0.03)$ & $(0.06)$ & $(0.03)$ & $(0.06)$ \\
\hline \multirow[t]{2}{*}{$\left(r_{j, t}-r_{i, t}\right) \cdot g_{1, t}$} & & $-1.00^{* * *}$ & & $-1.03^{* * *}$ & & $-1.05^{* * *}$ \\
\hline & & $(0.15)$ & & $(0.10)$ & & $(0.10)$ \\
\hline \multirow[t]{2}{*}{$\left(r_{j, t}-r_{i, t}\right) \cdot g_{2, t}$} & & $-0.46^{* * *}$ & & $-0.46^{* * *}$ & & $-0.47^{* * *}$ \\
\hline & & $(0.08)$ & & $(0.08)$ & & $(0.08)$ \\
\hline \multirow[t]{2}{*}{$g_{1, t}$} & & $0.01^{*}$ & & $-0.02^{* *}$ & & $-0.02^{* * *}$ \\
\hline & & $(0.01)$ & & $(0.01)$ & & $(0.01)$ \\
\hline \multirow[t]{2}{*}{$g_{2, t}$} & & $0.02^{* * *}$ & & -0.005 & & -0.005 \\
\hline & & $(0.004)$ & & $(0.01)$ & & $(0.006)$ \\
\hline Fund-country fixed effects & No & No & Yes & Yes & Yes & Yes \\
\hline Time fixed effects & No & No & No & No & Yes & Yes \\
\hline F-statistic & & $28.95^{* * *}$ & & $57.52^{* * *}$ & & $55.15^{* * *}$ \\
\hline Sample period & $1999 \mathrm{~m} 12$ & $-2012 m 12$ & $1999 \mathrm{~m} 12$ & $-2012 m 12$ & $1999 \mathrm{~m} 12$ & $-2012 m 12$ \\
\hline & 182,706 & 182,706 & 182,705 & 182,705 & 182,706 & 182,706 \\
\hline \multicolumn{7}{|c|}{$\begin{array}{l}\text { Note: The dependent variable is } \Delta \mathrm{w}_{i j, t} \text {. In column (1) and column (2), cluster-robust (clustered at the } \\
\text { fund-country level) standard errors are reported in parentheses. In column (3) and column (4), the } \\
\text { specifications include fund-country fixed effects while the specifications in column (5) and column (6) } \\
\text { include both fund-country fixed effects and time fixed effects. In column (3)-column (6), } \\
\text { heteroskedasticity- and autocorrelation-consistent Newey-West standard errors are reported in } \\
\text { parentheses. } g_{1, t} \text { is a dummy variable that takes a value of unity if a country's } \mathrm{MSCl} \text { local return } \\
\text { (evaluated at the local currency) correlation with the MSCl world return at each time } t \text { is greater } \\
\text { than the upper quartile in the sample, } g_{2, t} \text { if the correlation belongs to the interquartile range, and } \\
g_{3, t} \text { (omitted reference category) if it is smaller than the lower quartile. When creating these group } \\
\text { dummy variables, the time-varying moving-window return correlations are calculated based on the } \\
\text { monthly return data from January, } 1998 \text { to December, } 2012 \text { with a window size of } 24 \text { months. } \\
\text { F-statistics for a Wald test and their significance level are reported to test the joint significance of } \\
\text { coefficients for correlation ranking interaction terms. } * * *, * *, * \text { indicate statistical significance at the } \\
1 \%, 5 \% \text { and } 10 \% \text { levels, respectively. }\end{array}$} \\
\hline
\end{tabular}

earlier empirical studies that focus on the advanced country host markets (Hau and Rey, 2006, 2008).14) Additionally, one thing worth mentioning is that

14) Additionally, rebalancing far back toward an initial optimal allocation or only near the edge of the target allocation is an important issue in practice. And this decision may involve the transaction costs of the assets such as agent fees, operational costs and capital gain taxes. In the absence of the necessary data, our empirical analysis does not address the effect of the various transaction costs on portfolio rebalancing. 
rebalancing occurs even amongst foreign assets within mutual funds' equity portfolios. This implies that the currency risk may not be the only reason for portfolio rebalancing as emphasized in Hau and Rey (2006, 2008), which focuses on the portfolio allocations between home and foreign assets.

Next, we discuss estimated coefficients of Equation (11). Additional findings reported in Table 2 column (2) and column (4) are that, for both pooled OLS and FE estimation methods, the extent of rebalancing appears to be greater for a group of countries whose local return (evaluated at the local currency) correlation with the global return is larger. In other words, we discover the consistently higher degree of rebalancing in more integrated markets and can use Equation (12) to summarize our results such that $\beta+\gamma_{1}<\beta+\gamma_{2}<\beta+\gamma_{3}<0$ where $\gamma_{3}$ is the coefficient of the interaction term involving the omitted base category $g_{3, t}$. Intuitively, the equity assets in emerging economies that are more sensitive to global equity return movements bear the higher portfolio risk because the holdings of such assets tend to be exposed to the greater valuation changes and deteriorate the diversification benefits of international equity funds. This would lead to the higher degree of rebalancing from an emerging equity market that is more interdependent with the global equity market.

In addition to individual coefficient estimates and their standard errors, Table 2 also reports $F$-statistics (for a Wald test) for specifications that include interaction effects. Note that $t$-statistics for individual coefficient estimates are useful to see if each group interaction variable is statistically different from the other group. However, we need the $F$-statistics to test if overall differences amongst 3 groups are statistically significant. Table 2 shows that the $p$-values for the $F$-statistics testing the joint significance of group interaction variables are consistently below $1 \%$, validating our empirical specifications.

Finally, our main results in Table 2 complement the existing literature emphasizing that global common factors are partly responsible for cross-border aggregate capital flows (Calvo et al., 1996; Forbes and Warnock, 2012; Fratzscher, 2012; and Cerutti et al., 2014). 


\section{Other Control Variables}

This section discusses other factors that may affect the rebalancing behavior. Missing potentially relevant other factors, particularly if they are correlated with realized relative returns, would make our baseline results biased.

\subsection{Local Market Risk}

This paper's focus is on the valuation channel and its impact on the international funds' portfolio risk which in turn can affect the fund managers' portfolio choices. In addition to this valuation effect due to the realized return changes, the local equity market risk may also have a direct impact on the fund manager's portfolio reallocation decisions. Therefore, we test the robustness of our main results by controlling for the local equity market variance.

To measure the risk of returns for each host country, we calculate the monthly variance of the total return using the daily return data. The variance of return differs substantially across countries with the generally higher variance observed from less developed markets. For this reason, using the level of variance for each country in our panel data analysis would capture a difference in income levels rather than idiosyncratic market risks. Thus, we employ a relative variance shock instead of the level of variance as a country-specific market risk measure.

We first define a variance shock for each country as a deviation of the current month's variance from the average of the past three months and generate a time-varying variance shock of country $j$ return at time $t$ as follows: ${ }^{15}$ )

$$
V_{j t}=\operatorname{var}\left(r_{j t}\right)-\left(\left\{\Sigma_{k=1}^{3} \operatorname{var}\left(r_{j, t-k}\right)\right\} / 3\right)
$$

15) The choice of three months is arbitrary. Our results are robust to the longer periods of 6 or 12 months. Results can be provided upon request. 
Then, we obtain a relative variance shock for each country $\left(\Delta V_{i j, t}\right)$ as a deviation of country $j$ s variance shock $V_{j t}$ from the portfolio average variance shock $V_{i t}$ just like the definition of our relative total return in the baseline regression model:

$$
\begin{gathered}
\Delta V_{i j, t}=V_{j t}-V_{i t} \\
\text { where } V_{i t}=\Sigma_{j=1}^{J} \mathrm{~W}_{i j, t-1} V_{j t}
\end{gathered}
$$

\subsection{Fixed Exchange Rate Regimes with No Currency Risk}

We also test the validity of our results by controlling exchange rate regimes of the recipient country. Since the total return consists of the equity return evaluated at the local currency and the exchange rate return over the time period, equity holdings in a host country that uses the same currency as the fund domicile's make one less risk to worry about for international fund managers.

We set a dummy variable $\operatorname{peg}_{j, t}=1$ if the same currency is used in the fund domicile and investment destination under the fixed exchange rate regime at time $t$. For example, peg $_{j, t}$ takes a unity for euro zone funds that invest in the countries such as Austria, Finland, Greece, or Portugal that adopted euro during our sample period. Following the fine classification of Ilzetzki, Reinhart and Rogoff (2010), a country belongs to the category of peggers if it takes a de facto peg or pre announced band with margins of no larger than $+/-2 \%$. Information about periods with fixed exchange rates for sample countries is from the fine classification of Ilzetzki, Reinhart and Rogoff (2010) and is summarized in Table 3 .

\subsection{Stock Market Size}

For foreign portfolio investment decisions, the stock market size across countries may also play a role. Bekaert and Harvey (2000), Chan et al. (2005), 
Table 3. Countries with a Currency Peg, 1999m12-2010m12

\begin{tabular}{lll} 
Country & Pegging period & Anchor currency \\
Asia \& Pacific & & \\
China & $1999 \mathrm{~m} 12-2005 \mathrm{~m} 7 ; 2008 \mathrm{~m} 10-2010 \mathrm{~m} 12$ & US dollar \\
Hong Kong & $1999 \mathrm{~m} 12-2010 \mathrm{~m} 12$ & US dollar \\
Malaysia & $1999 \mathrm{~m} 12-2008 \mathrm{~m} 2$ & US dollar \\
Europe, Middle East \& Africa & & \\
Austria & $1999 \mathrm{~m} 12-2010 \mathrm{~m} 12$ & Euro \\
Czech Republic & $1999 \mathrm{~m} 12-2001 \mathrm{~m} 12$ & Euro \\
Finland & $1999 \mathrm{~m} 12-2010 \mathrm{~m} 12$ & Euro \\
Greece & $1999 \mathrm{~m} 12-2010 \mathrm{~m} 12$ & Euro \\
Hungary & $2009 \mathrm{~m} 10-2010 \mathrm{~m} 2$ & Euro \\
Portugal & $1999 \mathrm{~m} 12-2010 \mathrm{~m} 12$ & Euro \\
\hline
\end{tabular}

Note: This table summarizes countries with a currency peg against the US dollar or euro during our sample period. The pegging periods are selected based on the fine classification of Ilzetzki, Reinhart and Rogoff (2010). If the fine classification codes are less than 5, a country belongs to the category of (hard) peggers if it takes a de facto peg or pre announced band with margins of no larger than $+/-2 \%$. The currency regime data are available up to 2010 .

and Thapa and Poshakwale (2012) note that bigger and more developed equity markets tend to attract a greater volume of capital flows because not only are they more liquid and easier to observe market conditions but they also have higher market efficiency and lower transaction costs. Our interest is to see if the main results in Table 2 still hold when the market size is controlled.

To test the robustness of our baseline results controlling for the equity market size, we construct a relative market size variable $\left(\Delta M_{i j, t}\right)$ for fund i and country $j$ at time $t$ as follows:

$$
\begin{gathered}
\qquad \Delta M_{i j, t}=M_{j t}-M_{i t} \\
\text { where } M_{i t}=\Sigma_{j=1}^{J} \mathrm{~W}_{i j, t-1} M_{j t}
\end{gathered}
$$

where stock market size $M_{j t}$ is measured by the log of a country's stock market capitalization of listed companies as a percentage of GDP. 'Market capitalization (or market value) is defined as the share price times the number of shares 
outstanding for listed domestic companies' and the data, also used as a proxy to measure the market size in Levine and Zervos (1996), Chan et al. (2005) and Thapa and Poshakwale (2012), are from World Bank WDI.16) The original series is in an annual frequency and is interpolated using a constant-match average method in a monthly frequency to be consistent with the frequency of the other control variables.

\section{Robustness Results}

We extend the baseline model (9) and model (11) by adding country-specific control variables and their interactions as regressors of the active weight change and use the following two models for the robustness tests:

$$
\begin{gathered}
\Delta \mathrm{w}_{i j, t}=\alpha_{i j}+\beta \Delta\left(r_{j, t}-r_{i, t}\right)+\varphi \mathrm{z}_{j, t}+u_{i j, t} \\
\Delta \mathrm{w}_{i j, t}=\alpha_{i j}+\left(\beta+\sum_{k=1}^{3} \gamma_{k} g_{k, t}+\theta \mathrm{z}_{j, t}\right)\left(r_{j, t}-r_{i, t}\right)+\sum_{k=1}^{3} \delta_{k} g_{k, t}+\varphi \mathrm{z}_{j, t}+e_{i j, t}
\end{gathered}
$$

where $\left\{\Delta V_{i j, t}, P e g_{j, t}, \Delta M_{i j, t}\right\} \in z$ and $\alpha, \beta, \gamma, \delta, \theta$ and $\varphi$ are parameters to be estimated.

The first robustness results are displayed in Table 4. To save a space, we only report fixed effect estimations that control for unobserved heterogeneity across fund-country pairs. Indeed, the estimations based on the pooled OLS and based on two-way fixed effects produce similar results and they are available upon requests.

The magnitude of the estimated rebalancing coefficients reported in the first row of Table 4 is very close to the baseline results presented in the first row of Table 2. In particular, our first main result, $\beta<0$, is robust to controlling for the local market variance shock (column (1)), currency risk (columns (3)) and stock market size (column (5)) of the host countries. Controlling for various risk 
and market size factors, we find from column (2), column (4) and column (6) of Table 4 that the consistently higher degree of rebalancing in a more integrated equity market compared with the base category of the least globalized markets. Including all control variables together does not alter the results as shown in Table 4 column (7).

A few additional findings are worth noting here. Although the estimated coefficient for the local variance shock interaction term is not statistically significant, we find some suggestive evidence from a negative coefficient that local return uncertainty $\left(\Delta V_{i j, t}\right)$ tends to generate an additional rebalancing motive. And this result is consistent with the diversification objective of risk minimization. Furthermore, the local equity market size $\left(\Delta M_{i j, t}\right)$ tends to contribute to a greater rebalancing motive as a negative and statistically significant market size interaction term signifies. Rebalancing more from a bigger market may reflect the low transaction costs and high transparency that allow less costly portfolio shifts by fund managers.

On the other hand, as shown in column (4) of Table 4 by the positive and statistically significant $P e g_{j, t}$ interaction term, fund managers find lesser needs for rebalancing from countries whose equity markets involve little or no currency risk. This result verifies a currency-risk driven rebalancing hypothesis of Hau and Rey (2006, 2008); under a two-country (home and foreign) framework, they show that portfolio's foreign exchange exposure can increase when a foreign share of international portfolios gains in value with outperforming foreign assets. Active rebalancing by selling rising foreign assets and by buying falling domestic assets can stabilize investors' exposure to the foreign exchange risk. $\left.{ }^{17}\right)$

17) Hau and Rey (2008) also justify a wide use of portfolio rebalancing as a risk management instrument for international equity investments; equities do not have a predetermined maturity unlike fixed income securities, so it is hard to apply standard currency hedging instruments to equity holdings. 
Table 4. Robust Results Controlling for Risk Factors and Market Size

\begin{tabular}{|c|c|c|c|c|c|c|c|}
\hline \multirow{2}{*}{ Variable } & \multicolumn{2}{|c|}{ Local market risk } & \multicolumn{2}{|c|}{ Currency risk } & \multicolumn{2}{|c|}{ Market size } & \multirow{2}{*}{$\begin{array}{l}\text { All } \\
(7)\end{array}$} \\
\hline & $(1)$ & (2) & (3) & (4) & (5) & (6) & \\
\hline \multirow[t]{2}{*}{$r_{j, t}-r_{i, t}$} & $-0.64^{* * *}$ & $-0.23^{* * *}$ & $-0.64^{* * *}$ & $-0.23^{* * *}$ & $-0.63^{* * *}$ & $-0.12^{* *}$ & $-0.21^{* * *}$ \\
\hline & $(0.03)$ & $(0.06)$ & $(0.04)$ & $(0.07)$ & $(0.03)$ & $(0.06)$ & $(0.07)$ \\
\hline \multirow[t]{2}{*}{$\left(r_{j, t}-r_{i, t}\right) \cdot g_{1, t}$} & & $-0.98^{* * *}$ & & $-0.95^{* * *}$ & & $-1.04^{* * *}$ & $-0.88^{* * *}$ \\
\hline & & $(0.10)$ & & $(0.11)$ & & $(0.10)$ & $(0.11)$ \\
\hline \multirow[t]{2}{*}{$\left(r_{j, t}-r_{i, t}\right) \cdot g_{2, t}$} & & $-0.40^{* * *}$ & & $-0.49^{* * *}$ & & $-0.48^{* * *}$ & $-0.44^{* * *}$ \\
\hline & & $(0.08)$ & & $(0.08)$ & & $(0.08)$ & $(0.09)$ \\
\hline \multirow[t]{2}{*}{$\left(r_{j, t}-r_{i, t}\right) \cdot \Delta V_{i j, t}$} & & -0.24 & & & & & -0.33 \\
\hline & & $(0.29)$ & & & & & $(0.30)$ \\
\hline \multirow[t]{2}{*}{$\left(r_{j, t}-r_{i, t}\right) \cdot P e g_{j, t}$} & & & & $0.38^{* *}$ & & & $0.58^{* * *}$ \\
\hline & & & & $(0.15)$ & & & $(0.16)$ \\
\hline \multirow[t]{2}{*}{$\left(r_{j, t}-r_{i, t}\right) \cdot \Delta M_{i j,}$} & & & & & & $-0.001^{* * *}$ & $-0.002^{* * *}$ \\
\hline & & & & & & $(0.0004)$ & $(0.0005)$ \\
\hline \multirow[t]{2}{*}{$g_{1 t}$} & & $-0.02^{* *}$ & & $-0.02^{*}$ & & $-0.02^{* *}$ & -0.02 \\
\hline & & $(0.01)$ & & $(0.01)$ & & $(0.01)$ & $(0.01)$ \\
\hline \multirow[t]{2}{*}{$g_{2 t}$} & & -0.01 & & -0.003 & & -0.003 & 0.003 \\
\hline & & $(0.01)$ & & $(0.01)$ & & $(0.01)$ & $(0.01)$ \\
\hline \multirow[t]{2}{*}{$\Delta V_{i j, t}$} & $0.13^{* * *}$ & $0.11^{* *}$ & & & & & $0.12^{*}$ \\
\hline & $(0.05)$ & $(0.06)$ & & & & & $(0.06)$ \\
\hline \multirow[t]{2}{*}{$P e g_{j, t}$} & & & 0.002 & -0.002 & & & 0.002 \\
\hline & & & $(0.03)$ & $(0.03)$ & & & $(0.03)$ \\
\hline \multirow[t]{2}{*}{$\Delta M_{i j, t}$} & & & & & $-0.003^{* * *}$ & $-0.003^{* * *}$ & $-0.003^{* * *}$ \\
\hline & & & & & $(0.0001)$ & $(0.0001)$ & $(0.0001)$ \\
\hline F- statistic & & $49.4^{* * *}$ & & $38.7^{* * *}$ & & $58.8^{* * *}$ & $99.9^{* * *}$ \\
\hline Sample period & \multicolumn{2}{|c|}{ 1999m12-2012m12 } & \multicolumn{2}{|c|}{ 1999m12-2010m12 } & \multicolumn{2}{|c|}{ 1999m12-2012m12 } & $\begin{array}{l}1999 \mathrm{~m} 12- \\
2010 \mathrm{~m} 12\end{array}$ \\
\hline Observations & 181,238 & 181,238 & 143,966 & 143,966 & 176,435 & 176,435 & 137,533 \\
\hline
\end{tabular}

Note: This table shows the fixed-effect estimation results based on two models specified in Equation (16) and Equation (17) controlling for risk factors and the market size. The dependent variable is $\Delta \mathrm{w}_{i j, t}$. All specifications include fund-country fixed effects and heteroskedasticity- and autocorrelation-consistent Newey-West standard errors are reported in parentheses. $g_{1, t}$ is a dummy variable that takes a value of unity if a country's MSCl local return (evaluated at the local currency) correlation with the $\mathrm{MSCl}$ world return at each time $t$ is greater than the upper quartile in the sample, $g_{2, t}$ if the correlation belongs to the interquartile range, and $g_{3, t}$ (omitted reference category) if it is smaller than the lower quartile. When creating these group dummy variables, the time-varying moving-window return correlations are calculated based on the monthly return data from January, 1998 to December, 2012 with a window size of 24 months. The sample ends in 2010 in column (3) and column (4) because the exchange rate regime classification data (Ilzetzki, Reinhart and Rogoff, 2010) are available until 2010. F-statistics for a Wald test and their significance level are reported to test the joint significance of coefficients for correlation ranking interaction terms. ${ }^{* *}, * *, *$ indicate statistical significance at the $1 \%, 5 \%$ and $10 \%$ levels, respectively. 


\section{Additional Robustness Results}

We perform a couple of additional robustness checks and continue to find the consistent results. Looking at the contemporaneous relationship between portfolio adjustments and relative total returns does not allow fund managers' delayed responses. As a result, the rebalancing coefficient at time $t$ may underestimate the true portfolio reallocation behavior. To account for the equity trades that might occur with a time lag, we introduce one-period lag value of the relative returns and other explanatory variables to the baseline specifications. As seen from Table 5, the results regarding the coefficients of the contemporaneous relative returns and interaction terms remain almost the same as the main results in all specifications. The table also shows that the lagged interaction effects appear statistically insignificant in all cases. Moreover, the coefficients of lagged relative returns are small in both magnitude and statistical significance compared to the contemporaneous returns. In short, we find weak dynamic effect between the realized relative returns and portfolio country weight adjustments from our monthly data.

The main and robust results shown so far are based on the monthly frequency observations. Indeed, as noted earlier in Section 2, fund managers may have different portfolio adjustment time intervals. Some would rebalance on a monthly basis, but others may do at longer horizons. Hence, we consider a specification at the lower frequencies such as quarterly, semi-annul and annual that allows us to examine the relatively infrequent portfolio adjustments if they exist. Although some of the variables lose statistical significance under this smaller sample exercise, the lower-frequency results in Table 6 do not change the main message we have found so far. The results still support a rebalancing hypothesis and show a greater degree of rebalancing in an equity market with a stronger global linkage. 


\section{Table 5. Robust Results Controlling for Lagged Returns and Associated} Interaction Terms

\begin{tabular}{|c|c|c|c|c|c|c|}
\hline \multirow[b]{2}{*}{ Variable } & \multicolumn{2}{|c|}{ Pooled OLS } & \multicolumn{4}{|c|}{ Fixed-effect estimation } \\
\hline & (1) & (2) & (3) & (4) & (5) & (6) \\
\hline$r_{j, t}-r_{i, t}$ & $\begin{array}{l}-0.63^{* * *} \\
(0.07)\end{array}$ & $\begin{array}{l}-0.18^{* * *} \\
(0.06)\end{array}$ & $\begin{array}{l}-0.63^{* * *} \\
(0.03)\end{array}$ & $\begin{array}{l}-0.18^{* * *} \\
(0.06)\end{array}$ & $\begin{array}{l}-0.56^{* * *} \\
(0.03)\end{array}$ & $\begin{array}{l}-0.11^{*} \\
(0.06)\end{array}$ \\
\hline$\left(r_{j, t-1}-r_{i, t-1}\right)$ & $\begin{array}{l}-0.07^{*} \\
(0.04)\end{array}$ & $\begin{array}{l}-0.03 \\
(0.05)\end{array}$ & $\begin{array}{l}-0.07^{* *} \\
(0.03)\end{array}$ & $\begin{array}{l}-0.03 \\
(0.06)\end{array}$ & $\begin{array}{l}-0.07^{* *} \\
(0.03)\end{array}$ & $\begin{array}{l}-0.05 \\
(0.06)\end{array}$ \\
\hline$\left(r_{j, t}-r_{i, t}\right) \cdot g_{1, t}$ & & $\begin{array}{l}-1.01^{* * *} \\
(0.15)\end{array}$ & & $\begin{array}{l}-1.03^{* * *} \\
(0.10)\end{array}$ & & $\begin{array}{l}-1.05^{* * *} \\
(0.10)\end{array}$ \\
\hline$\left(r_{j, t}-r_{i, t}\right) \cdot g_{2, t}$ & & $\begin{array}{l}-0.47^{* * *} \\
(0.08)\end{array}$ & & $\begin{array}{l}-0.47^{* * *} \\
(0.08)\end{array}$ & & $\begin{array}{l}-0.47^{* * *} \\
(0.08)\end{array}$ \\
\hline$\left(r_{j, t-1}-r_{i, t-1}\right) \cdot g_{1, t-1}$ & & $\begin{array}{l}0.03 \\
(0.10)\end{array}$ & & $\begin{array}{l}-0.003 \\
(0.10)\end{array}$ & & $\begin{array}{l}0.104 \\
(0.10)\end{array}$ \\
\hline$\left(r_{j, t-1}-r_{i, t-1}\right) \cdot g_{2, t-1}$ & & $\begin{array}{l}-0.07 \\
(0.06)\end{array}$ & & $\begin{array}{l}-0.07 \\
(0.07)\end{array}$ & & $\begin{array}{l}-0.05 \\
(0.08)\end{array}$ \\
\hline$g_{1, t}$ & & $\begin{array}{l}0.01 \\
(0.01)\end{array}$ & & $\begin{array}{l}-0.01 \\
(0.01)\end{array}$ & & $\begin{array}{l}-0.01 \\
(0.01)\end{array}$ \\
\hline$g_{2, t}$ & & $\begin{array}{l}0.02^{* *} \\
(0.01)\end{array}$ & & $\begin{array}{l}0.01 \\
(0.01)\end{array}$ & & $\begin{array}{l}0.01 \\
(0.01)\end{array}$ \\
\hline$g_{1, t-1}$ & & $\begin{array}{l}-0.002 \\
(0.01)\end{array}$ & & $\begin{array}{l}-0.01 \\
(0.01)\end{array}$ & & $\begin{array}{l}-0.02 \\
(0.01)\end{array}$ \\
\hline$g_{2, t-1}$ & & $\begin{array}{l}-0.002 \\
(0.01)\end{array}$ & & $\begin{array}{l}-0.01 \\
(0.01)\end{array}$ & & $\begin{array}{l}-0.01 \\
(0.01)\end{array}$ \\
\hline Fund-country fixed effects & No & No & Yes & Yes & Yes & Yes \\
\hline Time fixed effects & No & No & No & No & Yes & Yes \\
\hline$F-$ statistic & & $29.40^{* * *}$ & & $56.34^{* * *}$ & & $53.73^{* * *}$ \\
\hline Sample period & $1999 \mathrm{~m} 12$ & $2012 \mathrm{~m} 12$ & $1999 \mathrm{~m} 12$ & $-2012 m 12$ & $1999 \mathrm{~m} 12$ & $-2012 m 12$ \\
\hline Observations & 182,090 & 182,090 & 182,089 & 182,089 & 182,089 & 182,089 \\
\hline
\end{tabular}

Note: This table shows the pooled OLS and fixed-effect estimation results based on two models specified in Equation (9) and Equation (11) controlling for lagged terms. The dependent variable is $\Delta \mathrm{w}_{i j, t}$. In column (1) and column (2), cluster-robust (clustered at the fund-country level) standard errors are reported in parentheses. In column (3) and column (4), the specifications include fund-country fixed effects while the specifications in column (5) and column (6) include both fund-country fixed effects and time fixed effects. In column (3)-column (6), heteroskedasticity- and autocorrelation-consistent Newey-West standard errors are reported in parentheses. $g_{1, t}$ is a dummy variable that takes a value of unity if a country's MSCl local return (evaluated at the local currency) correlation with the $\mathrm{MSCl}$ world return at each time $t$ is greater than the upper quartile in the sample, $g_{2, t}$ if the correlation belongs to the interquartile range, and $g_{3, t}$ (omitted reference category) if it is smaller than the lower quartile. When creating these group dummy variables, the time-varying moving-window return correlations are calculated based on the monthly return data from January, 1998 to December, 2012 with a window size of 24 months. F-statistics for a Wald test and their significance level are reported to test the joint significance of coefficients for correlation ranking interaction terms. $* * *, * *, *$ indicate statistical significance at the $1 \%, 5 \%$ and $10 \%$ levels, respectively. 


\section{Table 6. Robust Results Using Lower Frequency Data}

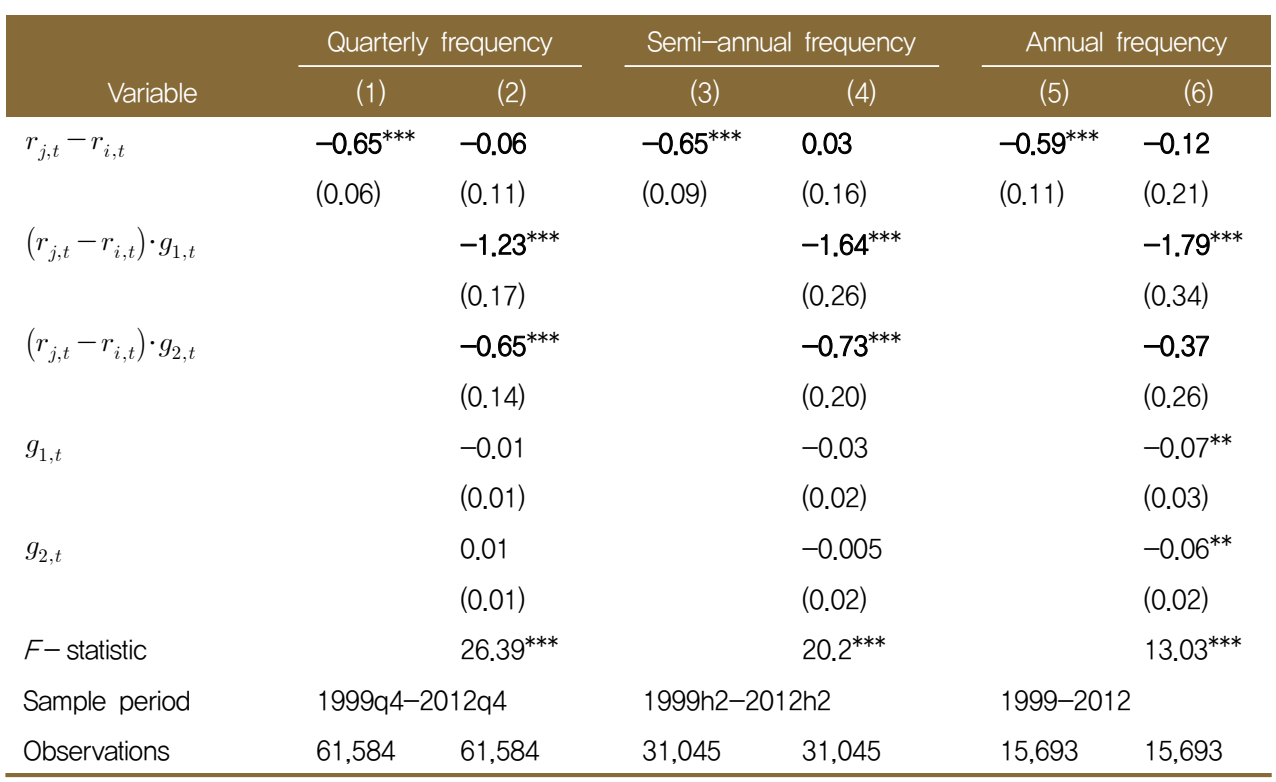

Note: This table shows the fixed-effect estimation results based on two models specified in Equation (9) and Equation (11) using lower frequency data (quarterly, half-annual, and annual). The dependent variable is $\Delta \mathrm{w}_{i j, t}$. All specifications include fund-country fixed effects and heteroskedasticity- and autocorrelation-consistent Newey-West standard errors are reported in parentheses. For a frequency conversion, we keep the lower frequency observation equal to the value in the last of the corresponding monthly observations. $g_{1, t}$ is a dummy variable that takes a value of unity if a country's $\mathrm{MSCl}$ local return (evaluated at the local currency) correlation with the $\mathrm{MSCl}$ world return at each time $t$ is greater than the upper quartile in the sample, $g_{2, t}$ if the correlation belongs to the interquartile range, and $g_{3, t}$ (omitted reference category) if it is smaller than the lower quartile. When creating these group dummy variables, the time-varying moving-window return correlations are calculated based on the monthly return data from January, 1998 to December, 2012 with a window size of 24 months. F-statistics for a Wald test and their significance level are reported to test the joint significance of coefficients for correlation ranking interaction terms. $* * * * *, *$ indicate statistical significance at the $1 \%$, $5 \%$ and $10 \%$ levels, respectively.

Lastly, our sample is unbalanced mainly due to frequent entries and exits of equity funds during the period 1999-2002. Testing our main hypotheses based on the balanced panel is performed with only 31 funds during the full sample period and with 121 funds during the shorter period 2003-2012 and it is summarized in Table A2 in Appendix. It again supports our main results. 


\section{Rebalancing during the 2008-09 Financial Crisis}

Given the severity of the global financial crisis in 2008-09, a majority of emerging economies in our sample were likely to undergo the large swings in cross-border capital flows. In particular, those equity markets that have a strong global linkage may have had volatile local equity returns due to the dramatic market turbulence in the advanced economies during the crisis. For emerging market fund managers, the global crisis can damage their portfolio returns and make their degree of risk aversion unusually high with a world-wide contraction of liquidity. To examine how the foreign fund managers' reallocation choices have changed as the host country faces the global crisis, we run rolling regressions with a window size of 3 years for the entire sample period.

From the estimation results in Table 7 Panel A, we see that the degree of portfolio rebalancing has been gradually rising (more negative rebalancing coefficient) as the host emerging markets were facing the global financial turbulence in 2008 and slowly reverting to the usual trade pattern afterwards. This result is in line with Vermeulen (2013) that documents that risk averse investors strongly rebalance their foreign investments towards relatively uncorrelated markets during the crisis to exploit diversification benefits. Looking at the results in Table 7 Panel B, the propensity of rebalancing from the markets that are most strongly correlated with the global market appears to be increasing and reaching its peak with a coefficient estimate of during the period 2006-08. From the second most integrated markets, the strongest rebalancing is found during the period 2008-10 with a coefficient estimate of. Except for one case in Panel B column (9), our main hypotheses $(\beta<0$ and $\beta+\gamma_{1}<\beta+\gamma_{2}<\beta+\gamma_{3}<0$ ) have been generally supported from rolling window regression results in Table 7 .

In general, risk-averse fund managers' active rebalancing by selling winners and by buying losers may have played a potentially stabilizing role in limiting the volatility of the host country's equity market. However, in crisis times, the risk-average fund managers' active rebalancing may place a sudden capital outflow pressure on the host country that has better weathered the crisis than the other countries within the portfolio. During the global crisis, this is an unfavorable outcome for the host country when everyone needs a great deal of liquidity. 


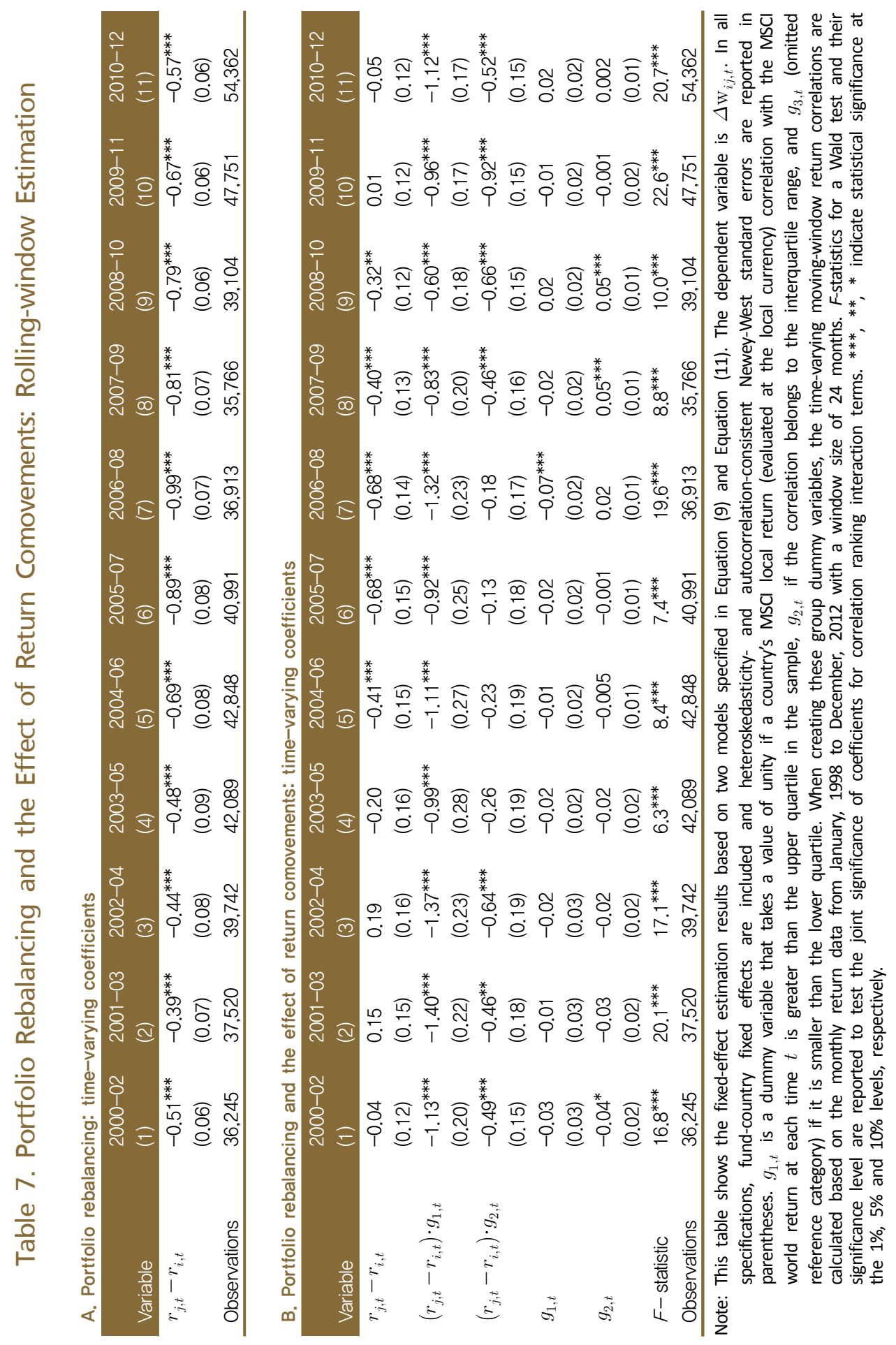




\section{Conclusion}

The main purpose of this paper is to provide a better understanding of portfolio adjustments by international equity mutual funds in response to valuation changes that stem from changes in local and global equity returns. With a greater degree of capital market interdependence and increasing volume of equity trading, stock returns exhibit a high degree of co-movement worldwide. This implies that the global factors may be at play in affecting the local equity return dynamics and accordingly international fund managers' portfolio managements.

This paper empirically analyzes portfolio allocation strategies of international mutual funds that hold only foreign equity assets in emerging economies. For that purpose, the paper uses the fund-level data that track country allocation in emerging equity markets around the world over the period 1999m12-2012m12. Important identification advantages that this data set offers are to worry less about the endogeneity resulting from reserve causality and the inference problem associated with the wealth effect.

Our empirical results show that fund managers, a majority of which reside in developed countries, manage their international portfolios by taking active rebalancing strategies by selling winners and by buying losers when facing realized relative return changes in emerging stock markets. The paper also finds that the host countries have heterogeneous exposures to global equity market conditions since their equity return correlation with the global return varies much over time and across countries. Interestingly, a stronger comovement of the local equity market with the global market is associated with the greater degree of rebalancing. We interpret this result based on the optimal diversification; a strong local and global return correlation makes a portfolio's valuation effect more sensitive to the external shocks and it tends to undermine portfolio diversification gains of fund managers. Actively rebalanced portfolio would mitigate the valuation effects of asset return changes and keep the fund managers' preferred risk exposure over time.

Our main results hold when allowing for host country specific factors such as 
local equity return uncertainty, exchange rate risk and stock market size that may confound the portfolio adjustment choices. Furthermore, the risk averse equity fund managers display a stronger rebalancing motive during the global financial turbulence.

More globalized equity markets are more exposed to the global common shocks due to a stronger valuation effect. The portfolio rebalancing behavior has a potential implication in lessening the volatility of the host country's equity market because it is counter-cyclical to the market conditions of the host country. Formally testing this inference is beyond the scope of our paper and we leave it for future research. 


\section{References}

Bekaert, G. and Harvey, C.R. (1995), "Time-varying World Market Integration," Journal of Finance, Vol. 50, pp. 403-444.

Bekaert, G. and Harvey, C.R. (2000), "Foreign Speculator and Emerging Equity Markets," Journal of Finance, Vol. 55, pp. 565-613.

Bohn, H. and Tesar, L. (1996), "US Equity Investment in Foreign Markets: Portfolio Rebalancing or Return Chasing?," American Economic Review, Vol. 86, pp. $77-81$.

Brennan, M. and Cao, H. (1997), "International Portfolio Investment Flows," Journal of Finance, Vol. 52, pp. 1851-1880.

Broner, F., Gelos, G., and Reinhart, C. (2006), "When in Peril, Retrench: Testing the Portfolio Channel of Contagion," Journal of International Economics, Vol. 69, pp. 203-230.

Calvet, L., Campbell, J. and Sodini, P. (2009), "Fight or Flight? Portfolio Rebalancing by Individual Investors," Quarterly Journal of Economics, Vol. 124, pp. 301-348.

Calvo, G.A., Leiderman, L. and Reinhart, C.M. (1996), "Inflows of Capital to Developing Countries in the 1990s," Journal of Economic Perspectives, Vol. 10, pp. 123-139.

Cameron, A.C. and Trivedi, P.K. (2005), Microeconometrics: Methods and Applications, Cambridge University Press.

Campa, J.M. and Fernandes, N. (2006). "Sources of Gains from International Portfolio Diversification," Journal of Empirical Finance, Vol. 13, pp. 417-443.

Cappiello, L., De Santis, R. (2005), "Explaining Exchange Rate Dynamics: The Uncovered Equity Return Parity Condition," European Central Bank Working Paper No. 529. 
Cerutti, E., Claessens, S. and Ratnovski, L. (2014), "Global Liquidity and Drivers of Cross-border Bank Flows," IMF Working Paper No. WP/14/69.

Chan, K., Covrig, V., and Ng, L. (2005), "What Determines the Domestic Bias and Foreign Bias? Evidence from Mutual Fund Equity Allocations Worldwide," Journal of Finance, Vol. 60, pp. 1495-1534.

Chuhan, P., Claessens, S., and Mamingi, N. (1998), "Equity and Bond Flows to Latin America and Asia: The Role of Global and Country Factors," Journal of Development Economics, Vol. 55, pp. 439-463.

Curcuru, S., Thomas, C., Warnock, F., and Wongswan, J. (2011), "US International Equity Investment and Past and Prospective Returns," American Economic Review, Vol. 101, pp. 3440-3455.

Curcuru, S., Thomas, C., Warnock, F., Wongswan, J. (2014), "Uncovered Equity Parity and Rebalancing in International Portfolios," Journal of International Money and Finance, Vol. 47, pp. 86-99.

Ding, L., and Ma, J. (2013), "Portfolio Reallocation and Exchange Rate Dynamics," Journal of Banking and Finance, Vol. 37, pp. 3100-3124.

Edison, H. and Warnock, F. (2008), "Cross-border Listings, Capital Controls, and Equity Flows to Emerging Markets," Journal of International Money and Finance, Vol. 27, pp. 1013-1027.

Fernandez-Arias, E. (1996), "The new Wave of Private Capital Inflows: Push or Pull?," Journal of Development Economics, Vol. 48, pp. 389-418.

Fidora, M., Fratzscher, M., and Thimann, C. (2007), "Home Bias in Global Bond and Equity Markets: The Role of Real Exchange Rate Volatility," Journal of International Money and Finance, Vol. 26, pp. 631-655.

Forbes, K., Fratzscher, M., Kostka, T., and Straub, R. (2016), "Bubble Thy Neighbor: Portfolio Effects and Externalities from Capital Controls," Journal of International Economics, Vol. 99, pp. 85-104. 
Forbes, K. and Rigobon, R. (2002), "No Contagion, Only Interdependence: Measuring Stock Market Comovements," Journal of Finance, Vol. 57, pp. 2223-2261.

Forbes, K. and Warnock, F. (2012), "Capital Flow Waves: Surges, Stops, Flight, and Retrenchment," Journal of International Economics, Vol. 88, pp. 235-251.

Fratzscher, M. (2012), "Capital Flows, Push versus Pull Factors and the Global Financial Crisis," Journal of International Economics, Vol. 88, pp. 341-356.

Froot, K.A., O'connell, P.G., and Seasholes, M.S. (2001), "The Portfolio Flows of International Investors," Journal of Financial Economics, Vol. 59, pp. 151-193.

Gelos, G. and Wei, S. (2005), "Transparency and International Portfolio Holdings," Journal of Finance, Vol. 60, pp. 2987-3020.

Ghosh, A.R., Qureshi, M.S., Kim, J.I., and Zalduendo, J. (2014), "Surges," Journal of International Economics, Vol. 92, pp. 266-285.

Hau, H. and Rey, H. (2004), "Can Portfolio Rebalancing Explain the Dynamics of Equity Returns, Equity Flows, and Exchange Rates?," American Economic Review, Vol. 94, pp. 126-133.

Hau, H. and Rey, H. (2006), "Exchange Rates, Equity Prices, and Capital Flows," Review of Financial Studies, Vol. 19, pp. 273-317.

Hau, H. and Rey, H. (2008), "Global Portfolio Rebalancing under the Microscope,” NBER Working Paper No.14165.

Ilzetzki, E., Reinhart, C., and Rogoff, K. (2010), "Exchange Rate Arrangements Entering the $21^{\text {st }}$ Century: Which Anchor Will Hold?," Mimeo, University of Maryland and Harvard University, http://personal.lse.ac.uk/ilzetzki/IRRBack.htm.

Jotikasthira, C., Lundblad, C., and Ramadorai, T. (2012), "Asset Fire Sales and Purchases and the International Transmission of Funding Shocks," Journal of Finance, Vol. 67, pp. 2015-2050.

Kaminsky, G., Lyons, R.K., Schmukler, S.L. (2004), "Managers, Investors, and 
Crises: Mutual Fund Strategies in Emerging Markets," Journal of International Economics, Vol. 64, pp. 113-134.

Kim, H. (2011), "The Risk Adjusted Uncovered Equity Parity," Journal of International Money and Finance, Vol. 30, pp. 1491-1505.

Levine, R. and Zervos, S. (1996), "Stock Market Development and Long-run Growth," The World Bank Economic Review, Vol. 10, pp. 323-339.

Longin, F., Solnik, B. (1995), "Is the Correlation in International Equity Returns Constant: 1960-1990?," Journal of International Money and Finance, Vol. 14, pp. 3-26.

Markowitz, H. (1952), "Portfolio Selection," Journal of Finance, Vol. 7, pp. 77-91.

Miranda-Agrippino, S. and Rey, H. (2015), "World Asset Markets and the Global Financial Cycle," NBER Working Paper No. 21722.

Quinn, D.P. and Voth, H.-J. (2008), "A Century of Global Equity Market Correlations," American Economic Review, Vol. 98, pp. 535-540.

Raddatz, C. and Schmukler, S. (2012), "On the International Transmission of Shocks: Micro-evidence from Mutual Fund Portfolios," Journal of International Economics, Vol. 88, pp. 357-374.

Thapa, C. and Poshakwale, S.S. (2012), "Country-specific Equity Market Characteristics and Foreign Equity Portfolio Allocation," Journal of International Money and Finance, Vol. 31, pp. 189-211.

Vermeulen, R. (2013), "International Diversification during the Financial Crisis: A Blessing for Equity Investors?," Journal of International Money and Finance, Vol. 35, pp. 104-123.

Wei, S., Zhang, Z., and Du, Q. (2010), "Does the Global Fireman Inadvertently Add Fuel to the Fire? New Evidence from Institutional Investors' Response to IMF Program Announcements," Journal of International Money and Finance, Vol. 29, pp. 728-741. 


\section{Appendix}

Table A1: Period-average Equity Return Correlations

\begin{tabular}{|c|c|c|c|}
\hline Country & $\begin{array}{l}\text { Local equity return and } \\
\text { global return } \\
\text { (1) }\end{array}$ & $\begin{array}{l}\text { Total return and global } \\
\text { return } \\
\text { (2) }\end{array}$ & $\begin{array}{l}\text { Ratio of (1) to (2) } \\
\text { (3) }\end{array}$ \\
\hline Austria & 0.745 & 0.773 & 0.964 \\
\hline Brazil & 0.702 & 0.741 & 0.948 \\
\hline Chile & 0.555 & 0.674 & 0.824 \\
\hline China & 0.604 & 0.604 & 1.000 \\
\hline Colombia & 0.318 & 0.455 & 0.699 \\
\hline Czech Republic & 0.544 & 0.634 & 0.858 \\
\hline Finland & 0.647 & 0.737 & 0.877 \\
\hline Greece & 0.594 & 0.659 & 0.902 \\
\hline Hong Kong & 0.716 & 0.717 & 0.999 \\
\hline Hungary & 0.730 & 0.762 & 0.958 \\
\hline India & 0.579 & 0.618 & 0.938 \\
\hline Indonesia & 0.538 & 0.527 & 1.021 \\
\hline Israel & 0.540 & 0.617 & 0.876 \\
\hline Korea & 0.588 & 0.683 & 0.861 \\
\hline Malaysia & 0.455 & 0.485 & 0.937 \\
\hline Mexico & 0.716 & 0.793 & 0.903 \\
\hline Peru & 0.545 & 0.550 & 0.991 \\
\hline Philippines & 0.524 & 0.543 & 0.965 \\
\hline Poland & 0.684 & 0.763 & 0.897 \\
\hline Portugal & 0.646 & 0.717 & 0.900 \\
\hline Russia & 0.581 & 0.612 & 0.949 \\
\hline Singapore & 0.723 & 0.751 & 0.962 \\
\hline South Africa & 0.652 & 0.737 & 0.885 \\
\hline Taiwan & 0.625 & 0.657 & 0.951 \\
\hline Thailand & 0.564 & 0.595 & 0.948 \\
\hline Turkey & 0.522 & 0.607 & 0.859 \\
\hline Average & 0.601 & 0.654 & 0.918 \\
\hline Maximum & 0.745 & 0.793 & 1.021 \\
\hline Minimum & 0.318 & 0.455 & 0.699 \\
\hline Standard Deviation & 0.097 & 0.093 & 0.068 \\
\hline
\end{tabular}

Note: This table summarizes a correlation between the local currency-priced equity return and global return for each country in Column (1); and a correlation between the total return and global return in Column (2). The total return refers to a combination of the local equity return (evaluated at the local currency) and exchange rate return (change in the value of a local currency against the US dollar). Column (3) presents a ratio of two correlations reported in Column (1) and Column (2). Reported period-average correlations are calculated from the monthly returns between 1998 and 2012. 


\section{Table A2: Robust Results Using Balanced Panel}

\begin{tabular}{|c|c|c|c|c|}
\hline \multirow[b]{2}{*}{ Variable } & \multicolumn{2}{|c|}{ Balanced panel (31 funds) } & \multicolumn{2}{|c|}{ Balanced panel (121 funds) } \\
\hline & (1) & (2) & (3) & (4) \\
\hline \multirow[t]{2}{*}{$r_{j, t}-r_{i, t}$} & $-0.49^{* * *}$ & -0.18 & $-0.50^{* * *}$ & -0.04 \\
\hline & $(0.08)$ & $(0.14)$ & $(0.04)$ & $(0.08)$ \\
\hline \multirow[t]{2}{*}{$\left(r_{j, t}-r_{i, t}\right) \cdot g_{1, t}$} & & $-1.27^{* * *}$ & & $-1.37^{* * *}$ \\
\hline & & $(0.23)$ & & $(0.12)$ \\
\hline \multirow[t]{2}{*}{$\left(r_{j, t}-r_{i, t}\right) \cdot g_{2, t}$} & & -0.18 & & $-0.39^{* * *}$ \\
\hline & & $(0.17)$ & & $(0.09)$ \\
\hline \multirow[t]{2}{*}{$g_{1, t}$} & & $-0.03^{*}$ & & $-0.02^{* *}$ \\
\hline & & $(0.02)$ & & $(0.01)$ \\
\hline \multirow[t]{2}{*}{$g_{2, t}$} & & -0.01 & & -0.01 \\
\hline & & $(0.015)$ & & $(0.01)$ \\
\hline F-statistic & & $16.21^{* * *}$ & & $16.21^{* * *}$ \\
\hline Sample period & \multicolumn{2}{|c|}{ 1999m12-2012m12 } & \multicolumn{2}{|c|}{$2003 m 1-2012 m 12$} \\
\hline Observations & 27,537 & 27,537 & 81,581 & 81,581 \\
\hline
\end{tabular}

Note: This table shows the fixed-effect estimation results based on two models specified in Equations (9) and (11) using balanced samples. The dependent variable is $\Delta \mathrm{w}_{i j, t}$. All specifications include fund-country fixed effects and heteroskedasticity- and autocorrelation-consistent Newey-West standard errors are reported in parentheses. $g_{1, t}$ is a dummy variable that takes a value of unity if a country's MSCl local return (evaluated at the local currency) correlation with the $\mathrm{MSCl}$ world return at each time $t$ is greater than the upper quartile in the sample, $g_{2, t}$ if the correlation belongs to the interquartile range, and $g_{3, t}$ (omitted reference category) if it is smaller than the lower quartile. When creating these group dummy variables, the time-varying moving-window return correlations are calculated based on the monthly return data from January, 1998 to December, 2012 with a window size of 24 months. F-statistics for a Wald test and their significance level are reported to test the joint significance of coefficients for correlation ranking interaction terms. ${ }^{* * *}, * *, *$ indicate statistical significance at the $1 \%$, $5 \%$ and $10 \%$ levels, respectively. 


\section{$<$ Abstract in Korean $>$}

\section{주식시장 글로벌화와 포트폴리오 리밸런싱}

\section{김경근*, 이동원 ${ }^{* *}$}

본고는 주식시장의 글로벌화가 주식 뮤추얼펀드 투자자의 신흥국 자산 배분 에 미치는 영향을 살펴보았다. 155개 선진국 펀드의 월별데이터를 1999 2012 년에 걸쳐 실증분석한 결과, 위험회피 성향의 글로벌 투자자는 투자대상국의 초 과수익에 반응하여 해당 투자국의 포트폴리오 비중을 줄이는 리밸런싱 전략을 취하는 경향이 있는 것으로 나타났다. 또한 투자대상국이 글로벌 시장과 더 동 조화되어 있을수록 이러한 리밸런싱 경향이 더 크게 나타났다. 이 결과는 금융 시장 통합이 진전될수록 글로벌 시장과의 밀접한 수익률 동조화를 보이는 신흥 국의 평가효과는 더 민감하게 반응할 가능성이 높고, 이러한 국가에 투자하는 펀드의 포트폴리오 리스크가 증가할 수 있음을 시사한다.

핵심 주제어: 주식시장 동조화, 포트폴리오 배분, 포트폴리오 리밸런싱, 평가효과 JEL Classification: F3, G11, G15

\footnotetext{
* 한국은행 경제연구원 국제경제연구실 부연구위원 (전화:02-759-5396, E-mail: kkkim@bok.or.kr)

** Assistant Professor of Economics, University of California, Riverside (E-mail: dongwon.lee@ucr.edu)

본 연구내용은 집필자의 개인의견이며 한국은행의 공식견해와는 무관합니다. 따라서 본 논문의 내용을 보도하거나 인용할 경우에는 집필자 명을 반드시 명시하여 주시기 바랍니다.
} 


\section{$\mathrm{BOK}$ 경제연구 발간목록}

한국은행 경제연구원에서는 Working Paper인 『BOK 경제연구』를 수시로 발간하고 있습니다. 『BOK 경제연구』는 주요 경제 현상 및 정책 효과에 대한 직관적 설명 뿐 아니라 깊이 있는 이론 또는 실증 분석을 제공함으로써 엄밀한 논증에 초점을 두는 학술논문 형태의 연구이며 한국은행 직원 및 한국은행 연구용역사업의 연구 결과물이 수록되고 있습니다.

${ }^{\circledR} \mathrm{BOK}$ 경제연구』 는 한국은행 경제연구원 홈페이지(http://imer.bok.or.kr)에서 다운로드하여 보실 수 있습니다.

제2014-1 Network Indicators for Monitoring Intraday Liquidity in BOK-Wire+

2 중소기업에 대한 신용정책 효과

3 경제충격 효과의 산업간 공행성 분석

4 서비스업 발전을 통한 내외수 균형성장: 기대효과 및 리스크

5 Cross-country-heterogeneous and Time-varying Effects of Unconventional Monetary Policies in AEs on Portfolio Inflows to EMEs

6 인터넷뱅킹, 결제성예금 및 은행 수익성과의 관계 분석

7 Dissecting Foreign Bank Lending Behavior During the 2008-2009 Crisis

8 The Impact of Foreign Banks on Monetary Policy Transmission during the Global Financial Crisis of 2008-2009: Evidence from Korea

9 Welfare Cost of Business Cycles in Economies with Individual Consumption Risk

10 Investor Trading Behavior Around the Time of Geopolitical Risk Events: Evidence from South Korea

11 Imported-Inputs Channel of Exchange Rate Pass-Through: Evidence from Korean Firm-Level Pricing Survey
Seungjin Baek

Kimmo Soram ki . Jaeho Yoon

정호성·임호성

황선웅·민성환 ·

신동현 · 김기호

김승원 · 황광명

Kyoungsoo Yoon •

Christophe Hurlin

이동규·전봉걸

Moon Jung Choi •

Eva Gutierrez •

Maria Soledad Martinez Peria

Bang Nam Jeon •

Hosung Lim. Ji Wu

Martin Ellison •

Thomas J. Sargent

Young Han Kim •

Hosung Jung

Jae Bin Ahn -

Chang-Gui Park 


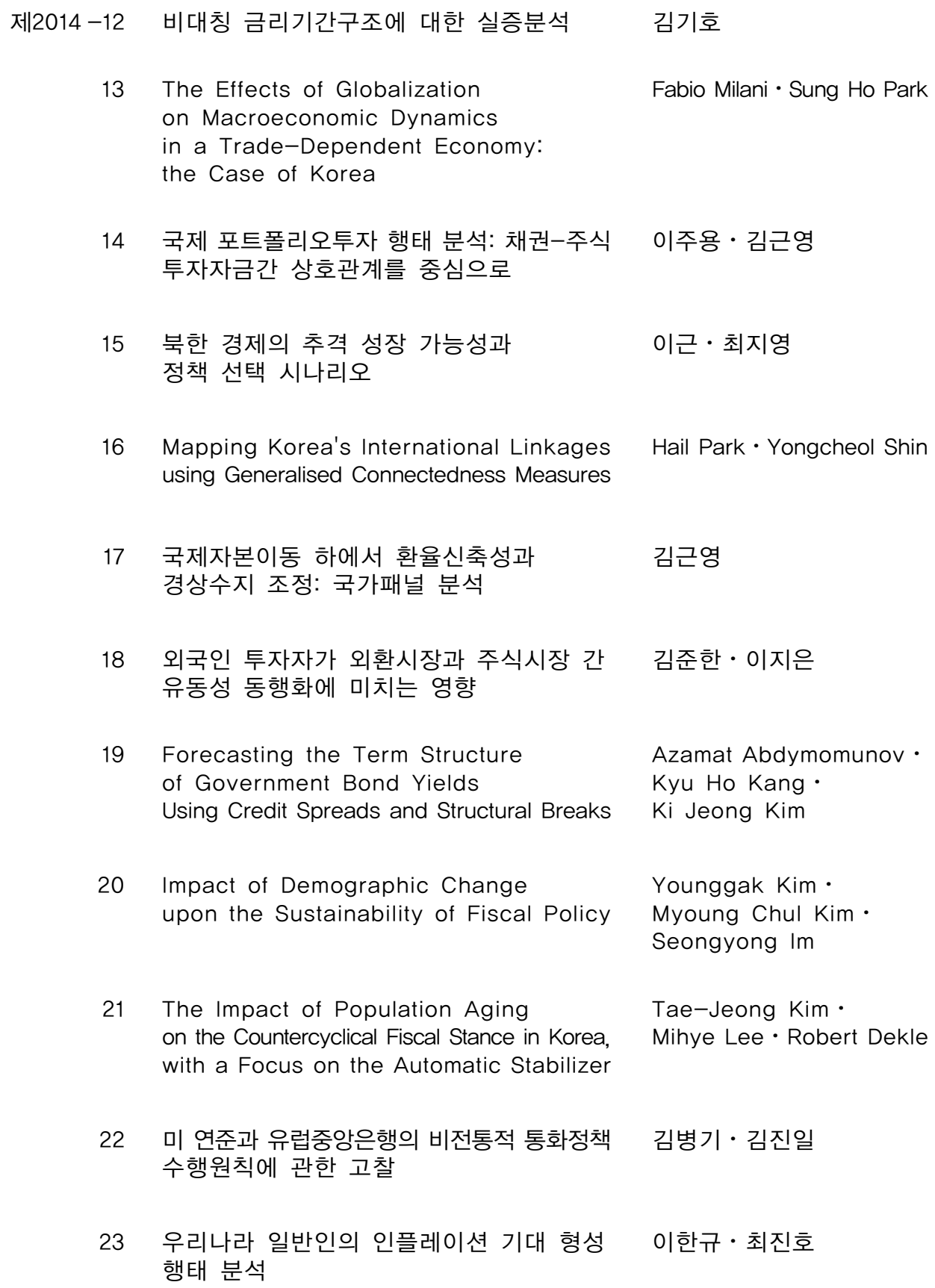

16 Mapping Korea's International Linkages using Generalised Connectedness Measures

17 국제자본이동 하에서 환율신축성과 경상수지 조정: 국가패널 분석

이주용·김근영

이근·최지영

Hail Park $\cdot$ Yongcheol Shin

18 외국인 투자자가 외환시장과 주식시장 간 유동성 동행화에 미치는 영향

19 Forecasting the Term Structure of Government Bond Yields Using Credit Spreads and Structural Breaks

20 Impact of Demographic Change upon the Sustainability of Fiscal Policy

21 The Impact of Population Aging on the Countercyclical Fiscal Stance in Korea, with a Focus on the Automatic Stabilizer

김근영

김준한 $\cdot$ 이지은

Azamat Abdymomunov •

Kyu Ho Kang.

Ki Jeong Kim

Younggak Kim •

Myoung Chul Kim.

Seongyong Im

Tae-Jeong Kim $\cdot$

Mihye Lee $\cdot$ Robert Dekle

22 미 연준과 유럽중앙은행의 비전통적 통화정책 수행원칙에 관한 고찰

김병기·김진일

23 우리나라 일반인의 인플레이션 기대 형성 행태 분석

이한규・최진호 
제2014-24 Nonlinearity in Nexus between

Working Hours and Productivity

25 Strategies for Reforming Korea's Labor Market to Foster Growth

26 글로벌 금융위기 이후 성장잠재력 확충: 2014 한국은행 국제컨퍼런스 결과보고서

27 인구구조 변화가 경제성장률에 미치는 영향: 자본이동의 역할에 대한 논의를 중심으로

28 Safe Assets

29 확장된 실업지표를 이용한 우리나라 노동시장에서의 이력현상 분석

Entropy of Global Financial Linkages

31 International Currencies Past, Present and Future: Two Views from Economic History

32 금융체제 이행 및 통합 사례:

남북한 금융통합에 대한 시사점

Measuring Price-Level Uncertainty and Instability in the U.S., 1850-2012

고용보호제도가 노동시장 이원화

및 노동생산성에 미치는 영향

35 해외충격시 외화예금의 역할 : 주요 신흥국 신용스프레드에 미치는 영향을 중심으로 Emerging Market Economies, and Their Policy Responses
Dongyeol Lee •

Hyunjoon Lim

Mai Dao · Davide Furceri ·

Jisoo Hwang .

Meeyeon Kim •

Tae-Jeong Kim

한국은행 경제연구원

손종칠

Robert J. Barro

김현학 · 황광명

Daeyup Lee

Barry Eichengreen

김병연

Timothy Cogley •

Thomas J. Sargent

김승원

정호성 - 우준명

김인수 · 이명수

황광명 · 김경민 ·

노충식·김미진

Woon Gyu Choi •

Taesu Kang •

Geun-Young Kim •

Byongju Lee 
제2015-1 글로벌 금융위기 이후 주요국

통화정책 운영체계의 변화

2 미국 장기시장금리 변동이 우리나라 금리기간구조에 미치는 영향 분석 및 정책적 시사점

3 직간접 무역연계성을 통한 해외충격의 우리나라 수출입 파급효과 분석

4 통화정책 효과의 지역적 차이

5 수입중간재의 비용효과를 고려한 환율변동과 수출가격 간의 관계

6 중앙은행의 정책금리 발표가 주식시장 유동성에 미치는 영향

7 은행 건전성지표의 변동요인과 거시건전성 규제의 영향

8 Price Discovery and Foreign Participation in The Republic of Korea's Government Bond Futures and Cash Markets

9 규제가 노동생산성에 미치는 영향:

한국의 산업패널 자료를 이용한 실증분석

10 인구 고령화와 정년연장 연구

(세대 간 중첩모형(OLG)을 이용한 정량 분석)

11 예측조합 및 밀도함수에 의한 소비자물가 상승률 전망

12 인플레이션 동학과 통화정책

13 Failure Risk and the Cross-Section of Hedge Fund Returns

14 Global Liquidity and Commodity Prices

15 Foreign Ownership, Legal System and Stock Market Liquidity
김병기·김인수

강규호·오형석

최문정·김근영

김기호

김경민

이지은

강종구

Jaehun Choi - Hosung Lim •

Rogelio Jr. Mercado •

Cyn-Young Park

이동렬 - 최종일 - 이종한

홍재화 - 강태수

김현학

우준명

Jung-Min Kim

Hyunju Kang ·

Bok-Keun $\mathrm{Yu}$.

Jongmin $\mathrm{Yu}$

Jieun Lee $\cdot$ Kee H. Chung 
제2015-16 바젤피 은행 경기대응완충자본 규제의 기준지표에 대한 연구

17 우리나라 대출 수요와 공급의 변동요인 분석

18 북한 인구구조의 변화 추이와 시사점

19 Entry of Non-financial Firms and Competition in the Retail Payments Market

20 Monetary Policy Regime Change and Regional Inflation Dynamics: Looking through the Lens of Sector-Level Data for Korea

21 Costs of Foreign Capital Flows in Emerging Market Economies: Unexpected Economic Growth and Increased Financial Market Volatility

22 글로벌 금리 정상화와 통화정책 과제: 2015년 한국은행 국제컨퍼런스 결과보고서

23 The Effects of Global Liquidity on Global Imbalances

24 실물경기를 고려한 내재 유동성 측정

25 Deflation and Monetary Policy

26 Macroeconomic Shocks and Dynamics of Labor Markets in Korea

27 Reference Rates and Monetary Policy Effectiveness in Korea

29 An Analysis of Trade Patterns in East Asia and the Effects of the Real Exchange Rate Movements

30 Forecasting Financial Stress Indices in Korea: A Factor Model Approach
서현덕·이정연

강종구 · 임호성

최지영

Jooyong Jun

Chi-Young Choi •

Joo Yong Lee

Roisin O'Sullivan

Kyoungsoo Yoon • Jayoung Kim

한국은행 경제연구원

Marie-Louise DJIGBENOU-KRE •

Hail Park

우준명·이지은

Barry Eichengreen

Tae Bong Kim •

Hangyu Lee

Heung Soon Jung •

Dong Jin Lee.

Tae Hyo Gwon .

Se Jin Yun

Bongseok Choi •

Wooyoung Park.

Bok-Keun Yu

Moon Jung Choi

Geun-Young Kim • Joo Yong Lee

Hyeongwoo Kim $\cdot$ Hyun Hak Kim. Wen Shi 


\begin{tabular}{|c|c|c|}
\hline 제2016 -1 & $\begin{array}{l}\text { The Spillover Effects of U.S. Monetary } \\
\text { Policy on Emerging Market Economies: } \\
\text { Breaks, Asymmetries and } \\
\text { Fundamentals }\end{array}$ & $\begin{array}{l}\text { Geun-Young Kim } \cdot \\
\text { Hail Park· } \\
\text { Peter Tillmann }\end{array}$ \\
\hline 2 & $\begin{array}{l}\text { Pass-Through of Imported Input Prices } \\
\text { to Domestic Producer Prices: Evidence } \\
\text { from Sector-Level Data }\end{array}$ & $\begin{array}{l}\text { JaeBin Ahn } \\
\text { Chang-Gui Park } \\
\text { Chanho Park }\end{array}$ \\
\hline 3 & $\begin{array}{l}\text { Spillovers from U.S. Unconventional } \\
\text { Monetary Policy and Its Normalization } \\
\text { to Emerging Markets: A Capital Flow } \\
\text { Perspective }\end{array}$ & $\begin{array}{l}\text { Sangwon Suh } \\
\text { Byung-Soo Koo }\end{array}$ \\
\hline 4 & $\begin{array}{l}\text { Stock Returns and Mutual Fund Flows } \\
\text { in the Korean Financial Market: } \\
\text { A System Approach }\end{array}$ & $\begin{array}{l}\text { Jaebeom Kim. } \\
\text { Jung-Min Kim }\end{array}$ \\
\hline 5 & $\begin{array}{l}\text { 정책금리 변동이 성별·세대별 고용률에 } \\
\text { 미치는 영향 }\end{array}$ & 정성엽 \\
\hline 6 & $\begin{array}{l}\text { From Firm-level Imports to Aggregate } \\
\text { Productivity: Evidence from Korean } \\
\text { Manufacturing Firms Data }\end{array}$ & $\begin{array}{l}\text { JaeBin Ahn } \\
\text { Moon Jung Choi }\end{array}$ \\
\hline 7 & $\begin{array}{l}\text { 자유무역협정(FTA)이 한국 기업의 } \\
\text { 기업내 무역에 미친 효과 }\end{array}$ & 전봉걸 $\cdot$ 김은숙 $\cdot$ 이주용 \\
\hline 8 & $\begin{array}{l}\text { The Relation Between Monetary and } \\
\text { Macroprudential Policy }\end{array}$ & Jong Ku Kang \\
\hline 9 & $\begin{array}{l}\text { 조세피난처 투자자가 투자 기업 및 주식 } \\
\text { 시장에 미치는 영향 }\end{array}$ & 정호성·김순호 \\
\hline 10 & $\begin{array}{l}\text { 주택실거래 자료를 이용한 주택부문 거시 } \\
\text { 건전성 정책 효과 분석 }\end{array}$ & 정호성·이지은 \\
\hline 11 & $\begin{array}{l}\text { Does Intra-Regional Trade Matter in } \\
\text { Regional Stock Markets?: New } \\
\text { Evidence from Asia-Pacific Region }\end{array}$ & $\begin{array}{l}\text { Sei-Wan Kim } \\
\text { Moon Jung Choi }\end{array}$ \\
\hline 12 & $\begin{array}{l}\text { Liability, Information, and Anti-fraud } \\
\text { Investment in a Layered Retail } \\
\text { Payment Structure }\end{array}$ & $\begin{array}{l}\text { Kyoung-Soo Yoon } \\
\text { Jooyong Jun }\end{array}$ \\
\hline 13 & $\begin{array}{l}\text { Testing the Labor Market Dualism in } \\
\text { Korea }\end{array}$ & $\begin{array}{l}\text { Sungyup Chung. } \\
\text { Sunyoung Jung }\end{array}$ \\
\hline 14 & $\begin{array}{l}\text { 북한 이중경제 사회계정행렬 추정을 통한 } \\
\text { 봉식부문 분석 }\end{array}$ & 최지영 \\
\hline
\end{tabular}




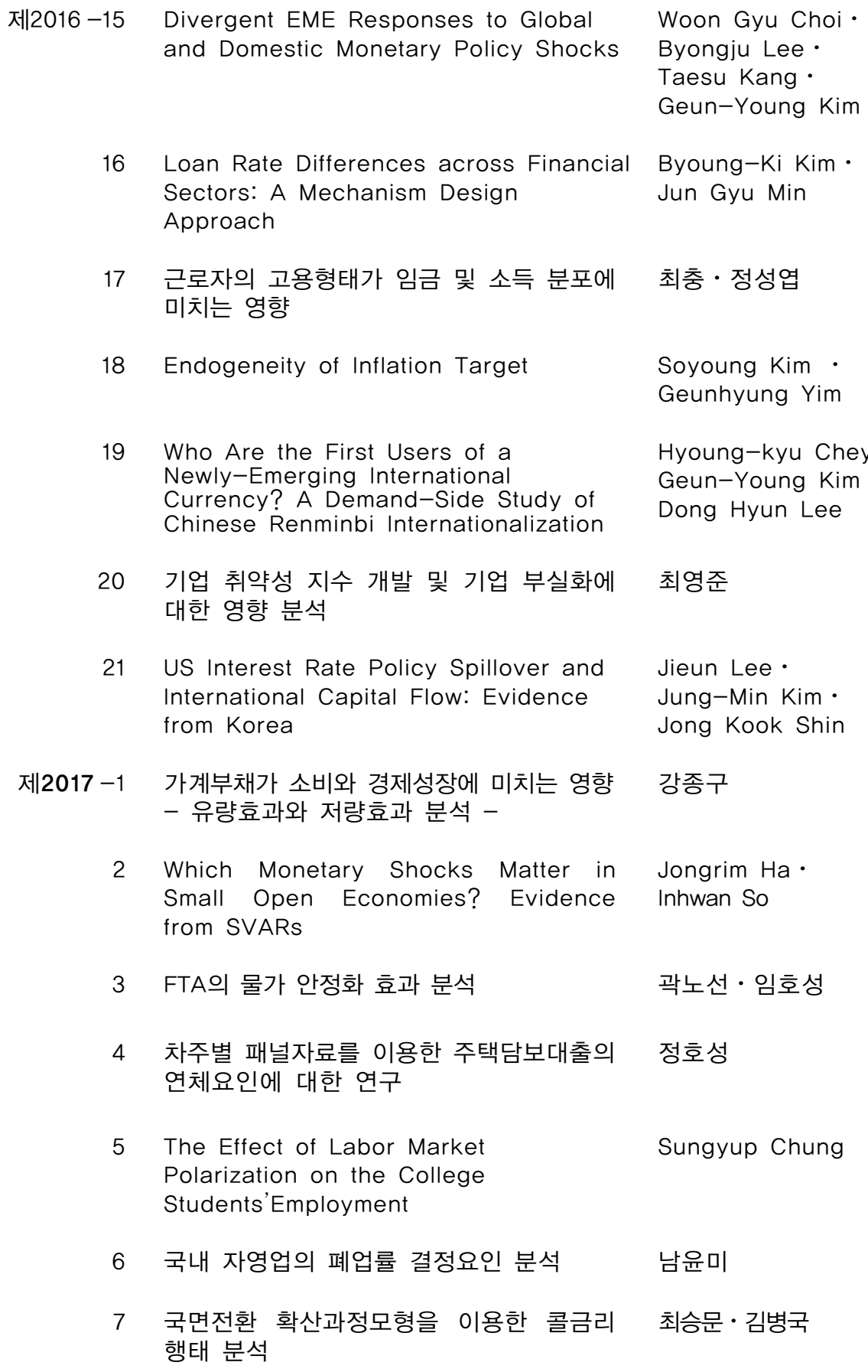

20 기업 취약성 지수 개발 및 기업 부실화에 최영준 대한 영향 분석

21 US Interest Rate Policy Spillover and International Capital Flow: Evidence from Korea

Jieun Lee Jung-Min Kim • Jong Kook Shin

제2017-1 가계부채가 소비와 경제성장에 미치는 영향 강종구

- 유량효과와 저량효과 분석 -

2 Which Monetary Shocks Matter in Jongrim $\mathrm{Ha} \cdot$ Small Open Economies? Evidence Inhwan So from SVARs

3 FTA의 물가 안정화 효과 분석 곽노선 - 임호성

4 차주별 패널자료를 이용한 주택담보대출의 정호성 연체요인에 대한 연구

5 The Effect of Labor Market

Sungyup Chung Polarization on the College Students'Employment

6 국내 자영업의 폐업률 결정요인 분석 남윤미

7 국면전환 확산과정모형을 이용한 콜금리 최승문·김병국 행태 분석 


\begin{tabular}{|c|c|c|}
\hline 제2017 -8 & $\begin{array}{l}\text { Behavioral Aspects of Household } \\
\text { Portfolio Choice: Effects of Loss } \\
\text { Aversion on Life Insurance Uptake } \\
\text { and Savings }\end{array}$ & In Do Hwang \\
\hline 9 & 신용공급 충격이 재화별 소비에 미치는 영향 & 김광환·최석기 \\
\hline 10 & 유가가 손익분기인플레이션에 미치는 영향 & 김진용 $\cdot$ 김준철 $\cdot$ 임형준 \\
\hline 11 & $\begin{array}{l}\text { 인구구조변화가 인플레이션의 장기 } \\
\text { 추세에 미치는 영향 }\end{array}$ & 강환구 \\
\hline 12 & $\begin{array}{l}\text { 종합적 상환여건을 반영한 과다부채 } \\
\text { 가계의 리스크 요인 분석 }\end{array}$ & 이동진·한진현 \\
\hline 13 & $\begin{array}{l}\text { Crowding out in a Dual Currency Regime? } \\
\text { Digital versus Fiat Currency }\end{array}$ & $\begin{array}{l}\text { KiHoon Hong } \cdot \\
\text { Kyounghoon Park } \\
\text { Jongmin } \mathrm{Yu}\end{array}$ \\
\hline 14 & $\begin{array}{l}\text { Improving Forecast Accuracy of } \\
\text { Financial Vulnerability: Partial Least } \\
\text { Squares Factor Model Approach }\end{array}$ & $\begin{array}{l}\text { Hyeongwoo Kim } \\
\text { Kyunghwan Ko }\end{array}$ \\
\hline 15 & $\begin{array}{l}\text { Which Type of Trust Matters?: } \\
\text { Interpersonal vs. Institutional vs. } \\
\text { Political Trust }\end{array}$ & In Do Hwang \\
\hline 16 & 기업특성에 따른 연령별 고용행태 분석 & 이상욱·권철우·남윤미 \\
\hline 17 & $\begin{array}{l}\text { Equity Market Globalization and } \\
\text { Portfolio Rebalancing }\end{array}$ & $\begin{array}{l}\text { Kyungkeun Kim } \\
\text { Dongwon Lee }\end{array}$ \\
\hline
\end{tabular}

